\title{
ЛОГІКА ПІДГОТОВКИ ЗДОБУВАЧІВ ВИЩОЇ ОСВІТИ СТУПЕНЯ ДОКТОРА ФІЛОСОФІї ЗІ СПЕЦІАЛІЗАЦІї «МЕДИЧНА ТА БІОЛОГІЧНА ІНФОРМАТИКА І КІБЕРНЕТИКА»
}

\author{
О. П. Мінцер, Л. Ю. Бабінцева \\ Національна медична академія післядипломної освіти імені П. Л. Шупика
}

\begin{abstract}
Представлено освітню програму та навчальний план підготовки здобувачів вищої освіти ступеня доктора фрілософрії на третьому (освітньо-науковому) рівні за всіма фрормами навчання для спеціалізації «Медична та біологічна інсрорматика і кібернетика». Навчання в аспірантурі та поза нею відбувається відповідно до Закону України «Про вищу освіту», постанов Кабінету Міністрів України від 23.03.2016 № 261 «Про затвердження Порядку підготовки здобувачів вищої освіти ступеня доктора фрілософії та доктора наук у вищих навчальних закладах (наукових установах)» та від 30.12.2015 № 1187 «Про затвердження Ліцензійних умов провадження освітньої діяльності закладів освіти».

Кінцеві цілі з навчальної дисципліни «Медична та біологічна інформатика і кібернетика» спрямовані на здобуття глибинних знань зі спеціальності, за якою здобувач проводить дослідження, зокрема засвоєння основних концепцій, розуміння теоретичних і практичних проблем, оволодіння термінологією з досліджуваного наукового напряму тощо.

Відомо, що навчальний план відповідно до наказу МОН України є нормативним документом (стандартом) закладу вищої освіти. Проте освітня програма та навчальний план складено на кафредрі медичної інформатики, що є опорною в системі післядипломної медичної освіти, тому запропоновані документи можуть розглядатись як унісрікована освітня програма та навчальний план.
\end{abstract}

Ключові слова: медична інорорматика та кібернетика, біологічна інформатика та кібернетика, навчальний план, освітня програма, компетентність, знання, вміння, самостійна робота.

\section{LOGIC OF STUDY OF HIGHER EDUCATION STUDENTS OF THE DOCTOR PHILOSOPHY OF SPECIALIZATION «MEDICAL AND BIOLOGICAL INFORMATICS AND CIBERNETICS»}

\author{
O. P. Mintser, L. Yu. Babintseva \\ Shupyk National Medical Academy of Postgraduate Education
}

\begin{abstract}
Background. The educational program and curriculum for the training of applicants for higher education degree of Ph.D. at the third (educational and scientific) level in all forms of education for the specialization «Medical and biological informatics and cybernetics» are presented. Education in graduate school and outside it takes place in accordance with the Law of Ukraine «On Higher Education», resolutions of the Ukrainian Cabinet of Ministers 03.23.2016 No. 261 «On Approval of the Procedure for Training Applicants for Higher Education to the degree of Ph.D. and Doctors of Science in higher educational institutions» and 12.30.2015 No. 1187 «On the approval of the Licensing Conditions for the implementation of educational activities of educational institutions».

Results. The final goals in the discipline «Medical and Biological Informatics and Cybernetics» are directed at obtaining in-depth knowledge of the specialty in which the applicant conducts research, in particular mastering basic concepts, understanding theoretical and practical problems, mastering the terminology in the scientific field under study, and other.

Conclusion. It is known that the curriculum in accordance with the order of the Ministry of Education and Science of Ukraine is a regulatory document (standard) of a higher education institution. However, the educational program and curriculum are drawn up at the Department of Medical Informatics, which is the core of the postgraduate medical education system, so the proposed documents can be considered as a unified educational program and curriculum.
\end{abstract}

Key words: medical informatics and cybernetics, biological informatics and cybernetics, curriculum, educational program, competence, knowledge, skills, independent work. 


\section{ЛОГИКА ПОДГОТОВКИ СОИСКАТЕЛЕЙ ВЫСШЕГО ОБРАЗОВАНИЯ СТЕПЕНИ ДОКТОРА ФИЛОСОФИИ ПО СПЕЦИАЛИЗАЦИИ «МЕДИЦИНСКАЯ И БИОЛОГИЧЕСКАЯ ИНФОРМАТИКА И КИБЕРНЕТИКА»

\author{
О. П. Минцер, Л. Ю. Бабинцева
}

Национальная медицинская академия последипломного образования имени П. Л. Шупика

Представлены образовательная программа и учебный план подготовки соискателей высшего образования степени доктора фрилософрии на третьем (образовательно-научном) уровне по всем фрормам обучения для специализации «Медицинская и биологическая информатика и кибернетика». Обучение в аспирантуре и вне ее происходит в соответствии с Законом Украины «О высшем образовании», постановлений Кабинета Министров Украины от 23.03.2016 № 261 «Об утверждении Порядка подготовки соискателей высшего образования степени доктора фрилософрии и доктора наук в высших учебных заведениях (научных учреждениях) « и от 30.12.2015 № 1187 «Об утверждении Лицензионных условий осуществления образовательной деятельности учебных заведений».

Конечные цели по дисциплине «Медицинская и биологическая инорорматика и кибернетика» направлены на получение глубинных знаний по специальности, по которой соискатель проводит исследования, в частности усвоение основных концепций, понимание теоретических и практических проблем, овладение терминологией по исследуемому научному направлению и другие.

Известно, что учебный план в соответствии с приказом МОН Украины является нормативным документом (стандартом) учреждения высшего образования. Однако образовательная программа и учебный план составлены на кафредре медицинской иноооматики, являющейся опорной в системе последипломного медицинского образования, поэтому предложенные документы могут рассматриваться как унифрицированная образовательная программа и учебный план.

Ключевые слова: медицинская информатика и кибернетика, биологическая информатика и кибернетика, учебный план, образовательная программа, компетентность, знания, умения, самостоятельная работа. 
Вступ. У Спільній декларації міністрів освіти Європи [1], підписаній у Болоньї 19 червня 1999 року, наголошується про підтримку принципів, викладених у Сорбонській декларації, координацію політики з метою досягнення у найближчому часі таких цілей, що мають першочергове значення для створення європейського простору вищої освіти та поширення європейської системи вищої освіти у світі. Болонський процес, Лісабонська конвенція [2] спрямовані на просування європейських стандартів у галузі вищої освіти, співробітництва між освітніми закладами стосовно розроблення навчальних планів, інтегрованих навчальних, дослідницьких і виховних програм.

В Україні однією з найважливіших сфер розвитку євроінтеграції є сфера вищої освіти. Відповідно відбуваються структурні зміни національної системи вищої освіти, що спрямовані не тільки на входження до європейського та світового наукового і освітнього простору, а й на підвищення спроможності випускників закладів вищої освіти до працевлаштування, покращення мобільності на ринку праці, безсумнівно, й підвищення конкурентоспроможності української вищої школи.

Будь-які зміни, пов'язані з процесом навчання, потребують відповідного кадрового, навчальнометодичного, інформаційного та інших видів забезпечення.

Спираючись на зміст ст. 5 Закону України «Про вищу освіту» зазначимо, що «...третій (освітньо-науковий) рівень вищої освіти відповідає восьмому кваліфікаційному рівню Національної рамки кваліфікацій і передбачає здобуття особою теоретичних знань, умінь, навичок та інших компетентностей, достатніх для продукування нових ідей, розв'язання комплексних проблем у галузі професійної та/або дослідницько-інноваційної діяльності, оволодіння методологією наукової та педагогічної діяльності, а також проведення власного наукового дослідження, результати якого мають наукову новизну, теоретичне та практичне значення...» [3].

Загальні цілі освітніх програм здобувачів вищої освіти ступеня доктора філософії (далі - здобувачі) спрямовано на: створення на основі інтеграції освіти та науки ефективної системи підготовки науково-педагогічних кадрів нової формації, здатних вирішувати питання вдосконалення суспільства, економіки, виробництва, науки та розроблення нових технологій; гармонізацію вітчизняних технологій підготовки науково-педагогічних кадрів вищої кваліфікації зі світовими стандартами, а також випереджаюче вирішення питань їх наукового, методичного, правового, фінансово-економічного, кадрового та матеріально-технічного забезпечення; реалізацію освітнього процесу відповідно до принципів міжнародної практики підготовки науково-педагогічних кадрів вищої кваліфікації, конкурентоспроможних на сучасному ринку праці. 3 цією метою здобувач проходить курс теоретичного навчання та здійснює самостійне оригінальне наукове дослідження. Результати дослідження оформляються у вигляді дисертаційної роботи, захист якої відбувається в установленому порядку.

Наукова спеціалізація з «Медичної та біологічної інформатики і кібернетики» - складова спеціальності, що передбачає профільну спеціалізовану освітньо-наукову програму підготовки здобувачів вищої освіти.

Для обговорення запропонована одна з найважливіших складових спеціалізації освітня програма підготовки здобувачів вищої освіти ступеня доктора філософії на третьому (освітньо-науковому) рівні за очною (денна, вечірня) та заочною формами навчання складена для здобувачів вищої освіти (далі - здобувачі), які навчаються в аспірантурі та поза аспірантурою, галузі знань: 22 - Охорона здоров'я та 09 - Біологія, спеціальностей: 224 - Технології медичної діагностики та лікування та 091 - Біологія. Навчання в аспірантурі та поза нею відбувається відповідно до Закону України «Про вищу освіту», постанов Кабінету Міністрів України від 23.03.2016 № 261 «Про затвердження Порядку підготовки здобувачів вищої освіти ступеня доктора філософії та доктора наук у вищих навчальних закладах (наукових установах)» та від 30.12.2015 № 1187 «Про затвердження Ліцензійних умов провадження освітньої діяльності закладів освіти» $[4,5]$.

Кінцеві цілі з навчальної дисципліни «Медична та біологічна інформатика і кібернетика» спрямовані на здобуття глибинних знань зі спеціальності, за якою здобувач проводить дослідження, зокрема засвоєння основних концепцій, розуміння теоретичних і практичних проблем, історії розвитку та сучасного стану наукових знань за обраною спеціальністю, оволодіння термінологією з досліджуваного наукового напряму.

Навчально-методичне забезпечення освітньої програми 3 навчальної дисципліни «Медична та біологічна інформатика і кібернетика» включає: програму навчальної дисципліни та навчальний 
план, заплановані результати навчання, оцінювання результатів навчання (характеристику оціночних ресурсів для поточного та проміжного контролю компетентностей, технологію проведення заліку, оціночні ресурси для поточного та підсумкового контролю засвоєння знань, оціночні ресурси для проміжної атестації за підсумками засвоєння дисципліни), рекомендовану літературу (основну, допоміжну), інформаційні ресурси в Інтернеті (електронні ресурси, предметно-тематичні каталоги), нормативні документи, а також навчально-методичне забезпечення самостійної роботи, ресурси самонавчання.

Мета роботи: представити для ознайомлення освітню програму та навчальний план із дисципліни «Медична та біологічна інформатика і кібернетика» для здобувачів вищої освіти ступеня доктора філософії на третьому (освітньо-науковому) рівні за очною (денна, вечірня) та заочною формами навчання. Програма складена для здобувачів вищої освіти, які навчаються в аспірантурі та поза аспірантурою, галузі знань: 22 - Охорона здоров’я та 09 - Біологія, спеціальностей: 224 - Технології медичної діагностики та лікування та 091 - Біологія. Запропонувати обговорення освітньої програми, розробленої на кафедрі медичної інформатики, що є опорною в системі післядипломної медичної освіти, з тим, щоб прийняти її як уніфіковану для зазначеної спеціалізації.

Результати та їх обговорення. Місце дисципліни в структурі освітньо-наукової програми здобувачів вищої освіти ступеня доктора філософії на третьому (освітньо-науковому) рівні. Медична та біологічна інформатика і кібернетика - системоутворюючий напрям знань. За своєю структурою він є міждисциплінарною та трансдисциплінарною дисципліною.

У XXI столітті комп’ютерні технології стали одним із найважливіших факторів, що впливають на розвиток суспільства. В рамках цього глобального процесу сучасний період розвитку медицини характеризується широким впровадженням інформаційно-комунікаційних технологій у діяльність органів управління охороною здоров’я, в практику роботи закладів охорони здоров'я (3О3), навчальних і наукових установ. Тому основні розділи медичної та біологічної інформатики і кібернетики включено в обов’ язкову частину освітньо-наукової програми здобувачів.

Сучасні комп’ютерні та інформаційні технології, інтеграція з мультимедійною інформацією уможливили практичну реалізацію впровадження автоматизованих систем оброблення медико-біологічної інформації на всіх рівнях системи охорони здоров'я.

Вивчення дисципліни базується на знаннях із питань інформатики, кібернетики, математики тощо. Здобувач зі спеціалізації «Медична та біологічна інформатика і кібернетика» повинен володіти термінологією з різних розділів інформатики та кібернетики, вміти користуватися операційними системами, володіти стандартним набором програмних засобів. Програма навчальної дисципліни передбачає вивчення закономірностей і принципів інформаційних процесів у медичних/біологічних системах різного рівня ієрархії, інженерію знань; процеси збору, збереження, оброблення та передавання інформації у біологічних і медичних системах; прийняття рішень у біології та медицині, а також ознайомлення 3 інформаційними технологіями досліджень, принципами моделювання, діагностики, а також інтердисциплінарні та трансдисциплінарні зв'язки медичної і біологічної інформатики з теоретичними та клінічними дисциплінами.

Мета засвоєння дисципліни - забезпечити набуття компетентностей, необхідних навиків та знань відповідно до Національної рамки кваліфікацій про методології створення та застосування в сучасній практичній і науковій діяльності здобувачів вищої освіти ступеня доктора філософії з таких основних кластерів знань: загальна інформатика; методи медичної та біологічної інформатики і кібернетики, клінічної інформатики; IT у системі охорони здоров'я; оброблення й аналіз даних медико-біологічних досліджень; математичне моделювання, прогнозування в охороні здоров'я та практичній медицині, синергетичні принципи дослідження медико-біологічних систем; телекомунікаційні технології, робототехніки, інформаційно-освітні технології, системи доповненої реальності, у т. ч. захист інформації в розподілених мережах; сучасні інформаційні технології в організації та функціонуванні медичної освіти, створення ситуаційних навчальних програм.

Навчальний план та програма дисципліни «Медична та біологічна інформатика і кібернетика» для здобувачів є нормативними документами, що визначають зміст навчання, встановлюють вимоги до рівня професійної підготовки. Зміст програми охоплює обсяг теоретичних 
знань, умінь, практичних навиків і професійних компетентностей.

Тривалість навчання: 2,0 місяця (12 кредитів, 360 годин).

Програма побудована за модульною системою. Модуль - самостійна частина програми, в якій подано значну за обсягом навчальну інформацію. Для полегшення орієнтації у програмі та впорядкування інформації модулі поділено на курси та розділи.

Навчальний план визначає тривалість навчання, розподіл годин, відведених на вивчення розділів програми, в тому числі самостійно та дистанційно. В разі необхідності, враховуючи рівень базисних знань, актуальність, специфіку завдань та інші обставини, кафедра може вносити корективи та доповнення в зміст розділів навчального плану та програми, а також розподіл годин, що регламентовані навчальним планом у межах 20 \% від загального обсягу часу.

Для виконання програми передбачено: 1) різні форми навчання (очна (денна, вечірня), заочна та очно-заочна з елементами дистанційного навчання, а також навчання на робочому місці; 2) різні види занять (лекційні, різновиди семінарських, практичні заняття, самостійна робота).

Для виявлення рівня знань, навиків і компетентностей здобувачів проводиться поточний, після кожного модулю - проміжний контроль знань за рахунок годин, передбачених на семінарські заняття. По закінченню навчання проводиться підсумковий контроль знань у формі заліку. Здобувачі, які успішно завершили навчання, допускаються до здавання кандидатського іспиту зі спеціальності. 


\section{ПРОГРАМА*}

з дисципліни «Медична та біологічна інформатика і кібернетика» для здобувачів вищої освіти ступеня доктора філософії (очна денна форма навчання)

\begin{tabular}{|c|c|c|c|c|}
\hline \multicolumn{4}{|c|}{ Кількість } & \multirow{2}{*}{$\begin{array}{c}\text { Форма } \\
\text { підсумкового } \\
\text { контролю }\end{array}$} \\
\hline Усього кредитів & Усього годин & Аудиторних годин & $\begin{array}{c}\text { Самостійна робота, } \\
\text { годин }\end{array}$ & \\
\hline 12 & 360 & 310 & 50 & Залік \\
\hline
\end{tabular}

\section{ПРОГРАМА}

з дисципліни «Медична та біологічна інформатика і кібернетика» для здобувачів вищої освіти ступеня доктора філософії (очна вечірня форма навчання)

\begin{tabular}{|c|c|c|c|c|}
\hline \multicolumn{4}{|c|}{ Кількість } & \multirow{2}{*}{$\begin{array}{c}\text { Форма } \\
\text { підсумкового } \\
\text { контролю }\end{array}$} \\
\hline Усього кредитів & Усього годин & Аудиторних годин & $\begin{array}{c}\text { Самостійна робота, } \\
\text { годин }\end{array}$ & \\
\hline 12 & 360 & 240 & 120 & Залік \\
\hline
\end{tabular}

\section{ПРОГРАМА}

з дисципліни «Медична та біологічна інформатика і кібернетика» для здобувачів вищої освіти ступеня доктора філософії (заочна форма навчання)

\begin{tabular}{|c|c|c|c|c|}
\hline \multicolumn{4}{|c|}{ Кількість } & \multirow{2}{*}{$\begin{array}{c}\text { Форма } \\
\text { підсумкового } \\
\text { контролю }\end{array}$} \\
\hline Усього кредитів & Усього годин & Аудиторних годин & $\begin{array}{c}\text { Самостійна робота, } \\
\text { годин }\end{array}$ & \\
\hline 12 & 360 & 120 & 240 & Залік \\
\hline
\end{tabular}

* Примітка. В розрахунку годин брали участь Краснов В. В., Мохначов С. I. 


\section{ПРОГРАМА \\ 3 дисципліни «Медична та біологічна інформатика і кібернетика» \\ для здобувачів вищої освіти ступеня доктора філософії \\ (очна (денна, вечірня), заочна форми навчання) \\ 22 - Охорона здоров’я, спеціальність 224 - Технології медичної діагностики та лікування \\ Тривалість навчання: 2,0 міс. (12 кредитів, 360 год.)}

\section{1. Інформатика як фундаментальна системо- утворююча наука.}

1.1. Базові питання загальної інформатики.

1.2. Програмно-прикладне забезпечення інформаційних технологій.

1.3. Системи прийняття рішень та автоматизовані інформаційні системи.

\section{2. Медична інформатика.}

2.1. Типи та стандарти медичної інформації.

2.2. Сучасні інформаційні технології у медичній галузях.

2.3. Інформаційні технології у медичній генетиці.

2.4. Основи аналізу медичних зображень.

2.5. Доказова медицина.

\section{3. Клінічна інформатика.}

3.1. Інформаційно-методологічні аспекти медичної діагностики.

3.2. Інформаційно-алгоритмічні основи діагностичних досліджень.

3.3. Автоматизовані системи діагностики захворювань.

4. Інформаційні технології у системі охорони здоров'я.

4.1. Інформаційні технології в управлінні медичною діяльністю.

4.2. Медичні інформаційні системи.

5. Оброблення й аналіз даних медичних досліджень.

5.1. Методи статистичного аналізу даних.

5.2. Елементи теорії ймовірностей і математичної статистики.

5.3. Методи оброблення медичних сигналів i даних.

5.4. Математичні основи аналізу медичних даних.

5.5. Комп’ютерний аналіз та інтерпретації медичних даних.

5.6. Прикладні аспекти застосування методів аналізу даних.

\section{6. Медична кібернетика.}

6.1. Медичні системи як об’єкт дослідження.

6.2. Методи та системи оптимізації у медичних дослідженнях.

6.3. Завдання оптимізації в управлінні та практичній медицині.

6.4. Реалізація методів кібернетики в практичній медицині.

6.5. Сучасні кібернетичні технології у медицині.

\section{7. Математичне моделювання.}

7.1. Основи математичного та комп’ютерного моделювання.

7.2. Методологія та програмно-математичне забезпечення.

7.3. Синергетичні принципи дослідження медико-біологічних систем.

7.4. Моделювання процесів у відкритих системах.

\section{8. Телекомунікаційні технології у медичній} галузі.

8.1. Телекомунікаційні мережі.

8.2. Концептуальні основи та технологічні питання телемедицини.

8.3. Захист інформації у розподілених мережах.

9. Сучасні інформаційні технології у медичній освіті.

9.1. Теоретичні засади інформатизації освіти.

9.2. Автоматизовані навчаючі системи.

9.3. Контроль знань у медичній освіті.

9.4. Інформаційні аспекти дистанційної освіти.

10. Новітні напрями медичної та біологічної інформатики.

10.1. Інформаційні аспекти мобільної медицини.

10.2. Інформаційні основи персоналізованої медицини.

10.3. Роботизована медицина.

10.4. Інформаційні аспекти симуляційної медицини.

10.5. Інформаційні аспекти наномедицини. 


\section{ПРОГРАМА}

з дисципліни «Медична та біологічна інформатика і кібернетика»

для здобувачів вищої освіти ступеня доктора філософії

(очна (денна, вечірня), заочна форми навчання)

09 - Біологія, спеціальність 091 - Біологія

Тривалість навчання: 2,0 міс. (12 кредитів, 360 год.)

\section{1. Інформатика як фундаментальна системо-} утворююча наука.

1.1. Базові питання загальної інформатики.

1.2. Програмно-прикладне забезпечення інформаційних технологій.

1.3. Системи прийняття рішень та автоматизовані інформаційні системи.

2. Методи інформатики в біологічних дослідженнях.

2.1. Сучасні інформаційні технології в біологічній галузі.

2.2. Біоінформатика та обчислювальна біологія.

2.3. Основи аналізу біологічних зображень.

2.4. Доказова медицина.

2.5. Інформаційно-методологічні аспекти біологічної діагностики.

2.6. Інформаційно-алгоритмічні основи діагностичних досліджень.

2.7. Інформаційні технології в управлінні.

2.8. Інформаційні технології у генетиці.

3. Оброблення й аналіз даних досліджень.

3.1. Методи статистичного аналізу даних.

3.2. Елементи теорії ймовірностей і математичної статистики.

3.3. Методи оброблення біологічних сигналів і даних.

3.4. Математичні основи аналізу даних.

3.5. Комп’ютерний аналіз та інтерпретації біологічних даних.

3.6. Прикладні аспекти застосування методів аналізу даних.

4. Біологічна кібернетика.

4.1. Біологічні системи як об’єкт дослідження.

4.2. Методи та системи оптимізації у біологічних дослідженнях.
4.3. Управління на різних рівнях організації системи.

4.4. Кібернетичне прогнозування в біології.

4.5. Геоінформаційні системи.

4.6. Сучасні кібернетичні технології у біології.

5. Математичне моделювання.

5.1. Основи математичного та комп'ютерного моделювання.

5.2. Методологія та програмно-математичне забезпечення.

5.3. Синергетичні принципи дослідження біологічних систем.

5.4. Моделювання процесів у відкритих системах.

\section{6. Телекомунікаційні технології.}

6.1. Телекомунікаційні мережі.

6.2. Технологічні питання передавання біологічної інформації.

6.3. Телемедицина.

6.4. Захист інформації у розподілених мережах.

7. Сучасні інформаційні технології в освіті.

7.1. Теоретичні засади інформатизації освіти.

7.2. Автоматизовані навчаючі системи.

7.3. Контроль знань у медичній освіті.

7.4. Інформаційні аспекти дистанційної освіти.

8. Новітні напрями біологічної та медичної інформатики.

8.1. Інформаційні аспекти мобільної медицини.

8.2. Інформаційні основи персоналізованої медицини.

8.3. Роботизована медицина.

8.4. Інформаційні аспекти симуляційної медицини.

8.5. Інформаційні аспекти наномедицини. 


\section{НАВЧАЛЬНИЙ ПЛАН}

дисципліни «Медична та біологічна інформатика і кібернетика» для здобувачів вищої освіти ступеня доктора філософії

(очна денна форма навчання)

22 - Охорона здоров’я, спеціальність 224 - Технології медичної діагностики та лікування

\begin{tabular}{|c|c|c|c|c|c|c|c|}
\hline \multirow{4}{*}{$\begin{array}{l}\text { № } \\
\text { 3/ח }\end{array}$} & \multirow[t]{4}{*}{ Модуль, курс } & \multicolumn{5}{|c|}{ Кількість годин } & \multirow{4}{*}{$\begin{array}{l}\text { Само- } \\
\text { стійна } \\
\text { робота }\end{array}$} \\
\hline & & \multirow{3}{*}{$\begin{array}{c}\text { Загаль- } \\
\text { ний } \\
\text { обсяг }\end{array}$} & \multicolumn{4}{|c|}{ аудиторних } & \\
\hline & & & \multirow[t]{2}{*}{ Всього } & \multicolumn{3}{|c|}{ у тому числі } & \\
\hline & & & & лекц & семін & практ & \\
\hline 1. & $\begin{array}{l}\text { Інформатика як фундаментальна систе- } \\
\text { моутворююча наука }\end{array}$ & 18 & 14 & 4 & 4 & 6 & 4 \\
\hline 1.1 & Базові питання загальної інформатики & & 2 & - & 2 & - & \\
\hline 1.2 & $\begin{array}{l}\text { Програмно-прикладне забезпечення інфор- } \\
\text { маційних технологій }\end{array}$ & & 4 & 2 & - & 2 & \\
\hline 1.3. & $\begin{array}{l}\text { Системи прийняття рішень та автоматизо- } \\
\text { вані інформаційні системи }\end{array}$ & & 8 & 2 & 2 & 4 & \\
\hline 2. & Медична інформатика & 42 & 32 & 6 & 8 & 18 & 10 \\
\hline 2.1 & Типи та стандарти медичної інформації & & 10 & 2 & 2 & 4 & \\
\hline 2.2 & $\begin{array}{l}\text { Сучасні інформаційні технології у медичній } \\
\text { галузях }\end{array}$ & & 4 & - & 2 & 2 & \\
\hline 2.3 & $\begin{array}{l}\text { Інформаційні технології } \\
\text { у медичній генетиці }\end{array}$ & & 8 & 2 & 2 & 4 & \\
\hline 2.4 & Основи аналізу медичних зображень & & 6 & 2 & - & 4 & \\
\hline 2.5 & Доказова медицина & & 6 & - & 2 & 4 & \\
\hline 3. & Клінічна інформатика & 40 & 34 & 6 & 12 & 16 & 6 \\
\hline 3.1 & $\begin{array}{l}\text { Інформаційно-методологічні аспекти ме- } \\
\text { дичної діагностики }\end{array}$ & & 12 & 2 & 4 & 6 & \\
\hline 3.2 & $\begin{array}{l}\text { Інформаційно-алгоритмічні основи } \\
\text { діагностичних досліджень }\end{array}$ & & 12 & 2 & 4 & 6 & \\
\hline 3.3 & $\begin{array}{l}\text { Автоматизовані системи діагностики за- } \\
\text { хворювань }\end{array}$ & & 10 & 2 & 4 & 4 & \\
\hline 4. & $\begin{array}{l}\text { Інформаційні технології у системі } \\
\text { охорони здоров’я }\end{array}$ & 20 & 18 & 4 & 4 & 10 & 2 \\
\hline 4.1 & $\begin{array}{l}\text { Інформаційні технології } \\
\text { в управлінні медичною діяльністю }\end{array}$ & & 8 & 2 & 2 & 4 & \\
\hline 4.2 & Медичні інформаційні системи & & 10 & 2 & 2 & 6 & \\
\hline 5. & $\begin{array}{l}\text { Оброблення й аналіз даних } \\
\text { медичних досліджень }\end{array}$ & 58 & 50 & 8 & 12 & 30 & 8 \\
\hline 5.1 & Методи статистичного аналізу даних & & 6 & 2 & - & 4 & \\
\hline 5.2 & $\begin{array}{l}\text { Елементи теорії ймовірностей і математич- } \\
\text { ної статистики }\end{array}$ & & 12 & 2 & 2 & 8 & \\
\hline 5.3 & $\begin{array}{l}\text { Методи оброблення медичних сигналів і } \\
\text { даних }\end{array}$ & & 6 & - & 2 & 4 & \\
\hline 5.4 & $\begin{array}{l}\text { Математичні основи аналізу медичних } \\
\text { даних }\end{array}$ & & 6 & 2 & - & 4 & \\
\hline 5.5 & $\begin{array}{l}\text { Комп’ютерний аналіз та інтерпретації ме- } \\
\text { дичних даних }\end{array}$ & & 10 & 2 & 4 & 4 & \\
\hline
\end{tabular}




\begin{tabular}{|c|c|c|c|c|c|c|c|}
\hline \multirow{4}{*}{$\begin{array}{l}\text { № } \\
\text { 3/п }\end{array}$} & \multirow[t]{4}{*}{ Модуль, курс } & \multicolumn{5}{|c|}{ Кількість годин } & \multirow{4}{*}{$\begin{array}{l}\text { Само- } \\
\text { стійна } \\
\text { робота }\end{array}$} \\
\hline & & \multirow{3}{*}{$\begin{array}{c}\text { Загаль- } \\
\text { ний } \\
\text { обсяг }\end{array}$} & \multicolumn{4}{|c|}{ аудиторних } & \\
\hline & & & \multirow[t]{2}{*}{ Всього } & \multicolumn{3}{|c|}{ у тому числі } & \\
\hline & & & & лекц & семін & практ & \\
\hline 5.6 & $\begin{array}{l}\text { Прикладні аспекти застосування } \\
\text { методів аналізу даних }\end{array}$ & & 10 & - & 4 & 6 & \\
\hline 6. & Медична кібернетика & 38 & 34 & 6 & 8 & 20 & 4 \\
\hline 6.1 & Медичні системи як об’єкт дослідження & & 6 & 2 & 2 & 2 & \\
\hline 6.2 & $\begin{array}{l}\text { Методи та системи оптимізації } \\
\text { у медичних дослідженнях }\end{array}$ & & 10 & 2 & 2 & 6 & \\
\hline 6.3 & $\begin{array}{l}\text { Завдання оптимізації в управлінні } \\
\text { та практичній медицині }\end{array}$ & & 8 & - & 2 & 6 & \\
\hline 6.4 & Сучасні кібернетичні технології у медицині & & 10 & 2 & 2 & 6 & \\
\hline 7. & Математичне моделювання & 42 & 38 & 8 & 8 & 22 & 4 \\
\hline 7.1 & $\begin{array}{l}\text { Основи математичного та комп’ютерного } \\
\text { моделювання }\end{array}$ & & 10 & 2 & 2 & 6 & \\
\hline 7.2 & $\begin{array}{l}\text { Методологія та програмно-математичне } \\
\text { забезпечення }\end{array}$ & & 10 & 2 & 2 & 6 & \\
\hline 7.3 & $\begin{array}{l}\text { Синергетичні принципи дослідження } \\
\text { медико-біологічних систем }\end{array}$ & & 8 & 2 & 2 & 4 & \\
\hline 7.4 & $\begin{array}{l}\text { Моделювання процесів у відкритих } \\
\text { системах }\end{array}$ & & 10 & 2 & 2 & 6 & \\
\hline 8. & $\begin{array}{l}\text { Телекомунікаційні технології } \\
\text { у медичній галузі }\end{array}$ & 24 & 20 & 6 & 4 & 10 & 4 \\
\hline 8.1 & Телекомунікаційні мережі & & 8 & 2 & 2 & 4 & \\
\hline 8.2 & $\begin{array}{l}\text { Концептуальні основи та технологічні } \\
\text { питання телемедицини }\end{array}$ & & 6 & 2 & - & 4 & \\
\hline 8.3 & Захист інформації у розподілених мережах & & 6 & 2 & 2 & 2 & \\
\hline 9. & $\begin{array}{l}\text { Сучасні інформаційні технології } \\
\text { у медичній освіті }\end{array}$ & 30 & 26 & 4 & 8 & 14 & 4 \\
\hline 9.1 & Теоретичні засади інформатизації освіти & & 6 & 2 & 2 & 2 & \\
\hline 9.2 & Автоматизовані навчаючі системи & & 6 & - & 2 & 4 & \\
\hline 9.3 & Контроль знань у медичній освіті & & 8 & 2 & 2 & 4 & \\
\hline 9.4 & Інформаційні аспекти дистанційної освіти & & 6 & - & 2 & 4 & \\
\hline 10. & $\begin{array}{l}\text { Новітні напрями медичної } \\
\text { та біологічної інформатики }\end{array}$ & 38 & 34 & 10 & 10 & 14 & 4 \\
\hline 10.1 & Інформаційні аспекти мобільної медицини & & 8 & 2 & 2 & 4 & \\
\hline 10.2 & $\begin{array}{l}\text { Інформаційні основи } \\
\text { персоналізованої медицини }\end{array}$ & & 10 & 2 & 4 & 4 & \\
\hline 10.3 & Роботизована медицина & & 4 & 2 & - & 2 & \\
\hline 10.4 & Інформаційні аспекти симуляційної медицини & & 8 & 2 & 2 & 4 & \\
\hline 10.5 & Інформаційні аспекти наномедицини & & 4 & 2 & 2 & - & \\
\hline & Контроль знань & 10 & & & 10 & & \\
\hline & Загалом & 360 & 310 & 62 & 88 & 160 & 50 \\
\hline
\end{tabular}




\section{НАВЧАЛЬНИЙ ПЛАН}

дисципліни «Медична та біологічна інформатика і кібернетика» для здобувачів вищої освіти ступеня доктора філософії

(очна вечірня форма навчання)

22 - Охорона здоров’я, спеціальність 224 - Технології медичної діагностики та лікування

\begin{tabular}{|c|c|c|c|c|c|c|c|}
\hline \multirow{4}{*}{$\begin{array}{l}\text { № } \\
\text { 3/ח }\end{array}$} & \multirow[t]{4}{*}{ Модуль, курс } & \multicolumn{5}{|c|}{ Кількість годин } & \multirow{4}{*}{$\begin{array}{l}\text { Само- } \\
\text { стійна } \\
\text { робота }\end{array}$} \\
\hline & & \multirow{3}{*}{$\begin{array}{c}\text { Загаль- } \\
\text { ний } \\
\text { обсяг }\end{array}$} & \multicolumn{4}{|c|}{ аудиторних } & \\
\hline & & & \multirow[t]{2}{*}{ всього } & \multicolumn{3}{|c|}{ у тому числі } & \\
\hline & & & & лекц & семін & практ & \\
\hline 1. & $\begin{array}{l}\text { Інформатика як фундаментальна } \\
\text { системоутворююча наука }\end{array}$ & 20 & 10 & 4 & 2 & 4 & 10 \\
\hline 1.1 & Базові питання загальної інформатики & & 2 & - & 2 & - & \\
\hline 1.2 & $\begin{array}{l}\text { Програмно-прикладне забезпечення } \\
\text { інформаційних технологій }\end{array}$ & & 4 & 2 & - & 2 & \\
\hline 1.3. & $\begin{array}{l}\text { Системи прийняття рішень та } \\
\text { автоматизовані інформаційні системи }\end{array}$ & & 4 & 2 & - & 2 & \\
\hline 2. & Медична інформатика & 42 & 22 & 4 & 10 & 8 & 20 \\
\hline 2.1 & Типи та стандарти медичної інформації & & 6 & 2 & 2 & 2 & \\
\hline 2.2 & $\begin{array}{l}\text { Сучасні інформаційні технології } \\
\text { у медичній галузях }\end{array}$ & & 4 & - & 2 & 2 & \\
\hline 2.3 & Інформаційні технології у медичній генетиці & & 4 & 2 & 2 & - & \\
\hline 2.4 & Основи аналізу медичних зображень & & 4 & - & 2 & 2 & \\
\hline 2.5 & Доказова медицина & & 4 & - & 2 & 2 & \\
\hline 3. & Клінічна інформатика & 40 & 30 & 6 & 12 & 12 & 10 \\
\hline 3.1 & $\begin{array}{l}\text { Інформаційно-методологічні аспекти } \\
\text { медичної діагностики }\end{array}$ & & 10 & 2 & 4 & 4 & \\
\hline 3.2 & $\begin{array}{l}\text { Інформаційно-алгоритмічні основи } \\
\text { діагностичних досліджень }\end{array}$ & & 10 & 2 & 4 & 4 & \\
\hline 3.3 & $\begin{array}{l}\text { Автоматизовані системи діагностики } \\
\text { захворювань }\end{array}$ & & 10 & 2 & 4 & 4 & \\
\hline 4. & $\begin{array}{l}\text { Інформаційні технології у системі } \\
\text { охорони здоров'я }\end{array}$ & 20 & 16 & 4 & 4 & 8 & 4 \\
\hline 4.1 & $\begin{array}{l}\text { Інформаційні технології в управлінні } \\
\text { медичною діяльністю }\end{array}$ & & 6 & 2 & 2 & 2 & \\
\hline 4.2 & Медичні інформаційні системи & & 10 & 2 & 2 & 6 & \\
\hline 5. & $\begin{array}{l}\text { Оброблення й аналіз даних } \\
\text { медичних досліджень }\end{array}$ & 58 & 36 & 8 & 6 & 22 & 22 \\
\hline 5.1 & Методи статистичного аналізу даних & & 4 & 2 & - & 2 & \\
\hline 5.2 & $\begin{array}{l}\text { Елементи теорії ймовірностей і математич- } \\
\text { ної статистики }\end{array}$ & & 8 & 2 & - & 6 & \\
\hline 5.3 & Методи оброблення медичних сигналів і даних & & 6 & - & 2 & 4 & \\
\hline 5.4 & Математичні основи аналізу медичних даних & & 6 & 2 & - & 4 & \\
\hline 5.5 & $\begin{array}{l}\text { Комп’ютерний аналіз та інтерпретації } \\
\text { медичних даних }\end{array}$ & & 6 & 2 & 2 & 2 & \\
\hline 5.6 & $\begin{array}{l}\text { Прикладні аспекти застосування } \\
\text { методів аналізу даних }\end{array}$ & & 6 & - & 2 & 4 & \\
\hline
\end{tabular}




\begin{tabular}{|c|c|c|c|c|c|c|c|}
\hline \multirow{4}{*}{$\begin{array}{l}\text { № } \\
\text { 3/п }\end{array}$} & \multirow[t]{4}{*}{ Модуль, курс } & \multicolumn{5}{|c|}{ Кількість годин } & \multirow{4}{*}{$\begin{array}{l}\text { Само- } \\
\text { стійна } \\
\text { робота }\end{array}$} \\
\hline & & \multirow{3}{*}{$\begin{array}{c}\text { Загаль- } \\
\text { ний } \\
\text { обсяг }\end{array}$} & \multicolumn{4}{|c|}{ аудиторних } & \\
\hline & & & \multirow[t]{2}{*}{ Всього } & \multicolumn{3}{|c|}{ у тому числі } & \\
\hline & & & & лекц & семін & практ & \\
\hline 6. & Медична кібернетика & 38 & 28 & 6 & 8 & 14 & 10 \\
\hline 6.1 & Медичні системи як об’єкт дослідження & & 6 & 2 & 2 & 2 & \\
\hline 6.2 & $\begin{array}{l}\text { Методи та системи оптимізації у медичних } \\
\text { дослідженнях }\end{array}$ & & 8 & 2 & 2 & 4 & \\
\hline 6.3 & $\begin{array}{l}\text { Завдання оптимізації в управлінні та прак- } \\
\text { тичній медицині } \\
\end{array}$ & & 6 & - & 2 & 4 & \\
\hline 6.4 & Сучасні кібернетичні технології у медицині & & 8 & 2 & 2 & 4 & \\
\hline 7. & Математичне моделювання & 42 & 32 & 8 & 8 & 16 & 10 \\
\hline 7.1 & $\begin{array}{l}\text { Основи математичного та комп’ютерного } \\
\text { моделювання }\end{array}$ & & 8 & 2 & 2 & 4 & \\
\hline 7.2 & $\begin{array}{l}\text { Методологія та програмно-математичне } \\
\text { забезпечення }\end{array}$ & & 8 & 2 & 2 & 4 & \\
\hline 7.3 & $\begin{array}{l}\text { Синергетичні принципи дослідження } \\
\text { медико-біологічних систем }\end{array}$ & & 6 & 2 & 2 & 2 & \\
\hline 7.4 & Моделювання процесів у відкритих системах & & 10 & 2 & 2 & 6 & \\
\hline 8. & $\begin{array}{l}\text { Телекомунікаційні технології } \\
\text { у медичній галузі }\end{array}$ & 24 & 14 & 6 & 2 & 6 & 10 \\
\hline 8.1 & Телекомунікаційні мережі & & 4 & 2 & - & 2 & \\
\hline 8.2 & $\begin{array}{l}\text { Концептуальні основи та технологічні пи- } \\
\text { тання телемедицини }\end{array}$ & & 6 & 2 & - & 4 & \\
\hline 8.3 & Захист інформації у розподілених мережах & & 4 & 2 & 2 & - & \\
\hline 9. & $\begin{array}{l}\text { Сучасні інформаційні технології } \\
\text { у медичній освіті }\end{array}$ & 30 & 18 & 4 & 6 & 8 & 12 \\
\hline 9.1 & Теоретичні засади інформатизації освіти & & 4 & 2 & 2 & - & \\
\hline 9.2 & Автоматизовані навчаючі системи & & 4 & - & 2 & 2 & \\
\hline 9.3 & Контроль знань у медичній освіті & & 6 & 2 & - & 4 & \\
\hline 9.4 & Інформаційні аспекти дистанційної освіти & & 4 & - & 2 & 2 & \\
\hline 10. & Новітні напрями медичної інформатики & 36 & 24 & 10 & 6 & 8 & 12 \\
\hline 10.1 & Інформаційні аспекти мобільної медицини & & 6 & 2 & 2 & 2 & \\
\hline 10.2 & $\begin{array}{l}\text { Інформаційні основи персоналізованої } \\
\text { медицини }\end{array}$ & & 6 & 2 & 2 & 2 & \\
\hline 10.3 & Роботизована медицина & & 4 & 2 & - & 2 & \\
\hline 10.4 & $\begin{array}{l}\text { Iнформаційні аспекти симуляційної меди- } \\
\text { цини }\end{array}$ & & 4 & 2 & - & 2 & \\
\hline 10.5 & Інформаційні аспекти наномедицини & & 4 & 2 & 2 & - & \\
\hline & Контроль знань & 10 & & & 10 & & \\
\hline & Загалом & 360 & 240 & 60 & 74 & 106 & 120 \\
\hline
\end{tabular}




\section{НАВЧАЛЬНИЙ ПЛАН}

дисципліни «Медична та біологічна інформатика і кібернетика» для здобувачів вищої освіти ступеня доктора філософії (заочна форма навчання)

22 - Охорона здоров’я, спеціальність 224 - Технології медичної діагностики та лікування

\begin{tabular}{|c|c|c|c|c|c|c|c|}
\hline \multirow{4}{*}{$\begin{array}{l}\text { № } \\
\text { 3/ח }\end{array}$} & \multirow[t]{4}{*}{ Модуль, курс } & \multicolumn{5}{|c|}{ Кількість годин } & \multirow{4}{*}{$\begin{array}{l}\text { Само- } \\
\text { стійна } \\
\text { робота }\end{array}$} \\
\hline & & \multirow{3}{*}{$\begin{array}{c}\text { Загаль- } \\
\text { ний } \\
\text { обсяг }\end{array}$} & \multicolumn{4}{|c|}{ аудиторних } & \\
\hline & & & \multirow[t]{2}{*}{ всього } & \multicolumn{3}{|c|}{ у тому числі } & \\
\hline & & & & лекц & семін & практ & \\
\hline 1. & $\begin{array}{l}\text { Інформатика як фундаментальна систе- } \\
\text { моутворююча наука }\end{array}$ & 20 & 4 & - & 2 & 2 & 16 \\
\hline 1.1 & Базові питання загальної інформатики & & - & - & - & - & \\
\hline 1.2 & $\begin{array}{l}\text { Програмно-прикладне забезпечення } \\
\text { інформаційних технологій }\end{array}$ & & 2 & - & - & 2 & \\
\hline 1.3. & $\begin{array}{l}\text { Системи прийняття рішень та автоматизова- } \\
\text { ні інформаційні системи }\end{array}$ & & 2 & - & 2 & - & \\
\hline 2. & Медична інформатика & 42 & 10 & 4 & 2 & 4 & 32 \\
\hline 2.1 & Типи та стандарти медичної інформації & & 2 & 2 & - & - & \\
\hline 2.2 & $\begin{array}{l}\text { Сучасні інформаційні технології у медичній } \\
\text { галузях }\end{array}$ & & 2 & - & 2 & - & \\
\hline 2.3 & Інформаційні технології у медичній генетиці & & 2 & 2 & - & - & \\
\hline 2.4 & Основи аналізу медичних зображень & & 2 & - & - & 2 & \\
\hline 2.5 & Доказова медицина & & 2 & - & - & 2 & \\
\hline 3. & Клінічна інформатика & 40 & 8 & 4 & 2 & 2 & 32 \\
\hline 3.1 & $\begin{array}{l}\text { Інформаційно-методологічні аспекти ме- } \\
\text { дичної діагностики }\end{array}$ & & 2 & 2 & - & - & \\
\hline 3.2 & $\begin{array}{l}\text { Інформаційно-алгоритмічні основи діагнос- } \\
\text { тичних досліджень }\end{array}$ & & 2 & - & 2 & - & \\
\hline 3.3 & $\begin{array}{l}\text { Автоматизовані системи діагностики за- } \\
\text { хворювань }\end{array}$ & & 4 & 2 & - & 2 & \\
\hline 4. & $\begin{array}{l}\text { Інформаційні технології у системі } \\
\text { охорони здоров'я }\end{array}$ & 20 & 12 & 2 & 4 & 6 & 8 \\
\hline 4.1 & $\begin{array}{l}\text { Інформаційні технології в управлінні } \\
\text { медичною діяльністю }\end{array}$ & & 6 & 2 & 2 & 2 & \\
\hline 4.2 & Медичні інформаційні системи & & 6 & - & 2 & 4 & \\
\hline 5. & $\begin{array}{l}\text { Оброблення й аналіз даних } \\
\text { медичних досліджень }\end{array}$ & 58 & 16 & 4 & 2 & 10 & 42 \\
\hline 5.1 & Методи статистичного аналізу даних & & 2 & - & 2 & - & \\
\hline 5.2 & $\begin{array}{l}\text { Елементи теорії ймовірностей і математич- } \\
\text { ної статистики }\end{array}$ & & 6 & 2 & - & 4 & \\
\hline 5.3 & Методи оброблення медичних сигналів і даних & & 2 & - & - & 2 & \\
\hline 5.4 & Математичні основи аналізу медичних даних & & 2 & 2 & - & - & \\
\hline 5.5 & $\begin{array}{l}\text { Комп’ютерний аналіз та інтерпретації } \\
\text { медичних даних }\end{array}$ & & - & - & - & - & \\
\hline 5.6 & $\begin{array}{l}\text { Прикладні аспекти застосування методів } \\
\text { аналізу даних }\end{array}$ & & 4 & - & - & 4 & \\
\hline
\end{tabular}




\begin{tabular}{|c|c|c|c|c|c|c|c|}
\hline \multirow{4}{*}{$\begin{array}{l}\text { № } \\
\text { 3/ח }\end{array}$} & \multirow[t]{4}{*}{ Модуль, курс } & \multicolumn{5}{|c|}{ Кількість годин } & \multirow{4}{*}{$\begin{array}{l}\text { Само- } \\
\text { стійна } \\
\text { робота }\end{array}$} \\
\hline & & \multirow{3}{*}{$\begin{array}{c}\text { Загаль- } \\
\text { ний } \\
\text { обсяг }\end{array}$} & \multicolumn{4}{|c|}{ аудиторних } & \\
\hline & & & \multirow[t]{2}{*}{ Всього } & \multicolumn{3}{|c|}{ у тому числі } & \\
\hline & & & & лекц & семін & практ & \\
\hline 6. & Медична кібернетика & 38 & 16 & 6 & 2 & 8 & 22 \\
\hline 6.1 & Медичні системи як об’єкт дослідження & & 2 & 2 & - & - & \\
\hline 6.2 & $\begin{array}{l}\text { Методи та системи оптимізації у медичних } \\
\text { дослідженнях }\end{array}$ & & 4 & - & 2 & 2 & \\
\hline 6.3 & $\begin{array}{l}\text { Завдання оптимізації в управлінні } \\
\text { та практичній медицині } \\
\end{array}$ & & 4 & 2 & - & 2 & \\
\hline 6.4 & Сучасні кібернетичні технології у медицині & & 6 & 2 & - & 4 & \\
\hline 7. & Математичне моделювання & 42 & 16 & 4 & 4 & 8 & 26 \\
\hline 7.1 & $\begin{array}{l}\text { Основи математичного та комп’ютерного } \\
\text { моделювання }\end{array}$ & & 4 & - & 2 & 2 & \\
\hline 7.2 & $\begin{array}{l}\text { Методологія та програмно-математичне } \\
\text { забезпечення }\end{array}$ & & 4 & - & 2 & 2 & \\
\hline 7.3 & $\begin{array}{l}\text { Синергетичні принципи дослідження } \\
\text { медико-біологічних систем }\end{array}$ & & 4 & 2 & - & 2 & \\
\hline 7.4 & Моделювання процесів у відкритих системах & & 4 & 2 & - & 2 & \\
\hline 8. & $\begin{array}{l}\text { Телекомунікаційні технології } \\
\text { у медичній галузі }\end{array}$ & 24 & 8 & 2 & 2 & 4 & 16 \\
\hline 8.1 & Телекомунікаційні мережі & & 4 & 2 & - & 2 & \\
\hline 8.2 & $\begin{array}{l}\text { Концептуальні основи та технологічні пи- } \\
\text { тання телемедицини }\end{array}$ & & 2 & - & - & 2 & \\
\hline 8.3 & Захист інформації у розподілених мережах & & 2 & - & 2 & - & \\
\hline 9. & $\begin{array}{l}\text { Сучасні інформаційні технології } \\
\text { у медичній освіті }\end{array}$ & 30 & 8 & 2 & 4 & 2 & 22 \\
\hline 9.1 & Теоретичні засади інформатизації освіти & & 2 & 2 & - & - & \\
\hline 9.2 & Автоматизовані навчаючі системи & & 2 & - & 2 & - & \\
\hline 9.3 & Контроль знань у медичній освіті & & 2 & - & - & 2 & \\
\hline 9.4 & Інформаційні аспекти дистанційної освіти & & 2 & - & 2 & - & \\
\hline 10. & Новітні напрями медичної інформатики & 36 & 12 & 6 & 4 & 2 & 24 \\
\hline 10.1 & Інформаційні аспекти мобільної медицини & & 2 & 2 & - & - & \\
\hline 10.2 & $\begin{array}{l}\text { Інформаційні основи персоналізованої } \\
\text { медицини }\end{array}$ & & 4 & 2 & - & 2 & \\
\hline 10.3 & Роботизована медицина & & 2 & - & 2 & - & \\
\hline 10.4 & $\begin{array}{l}\text { Інформаційні аспекти симуляційної меди- } \\
\text { цини }\end{array}$ & & 2 & - & 2 & - & \\
\hline 10.5 & Інформаційні аспекти наномедицини & & 2 & 2 & - & - & \\
\hline & Контроль знань & 10 & & & 10 & & \\
\hline & Загалом & 360 & 120 & 34 & 38 & 48 & 240 \\
\hline
\end{tabular}




\section{НАВЧАЛЬНИЙ ПЛАН}

дисципліни «Медична та біологічна інформатика і кібернетика»

для здобувачів вищої освіти ступеня доктора філософії

(очна денна форма навчання).

09 - Біологія, спеціальність 091 - Біологія

\begin{tabular}{|c|c|c|c|c|c|c|c|}
\hline \multirow{4}{*}{$\begin{array}{l}\text { № } \\
\text { 3/ח }\end{array}$} & \multirow[t]{4}{*}{ Модуль, курс } & \multicolumn{5}{|c|}{ Кількість годин } & \multirow{4}{*}{$\begin{array}{l}\text { Само- } \\
\text { стійна } \\
\text { робота }\end{array}$} \\
\hline & & \multirow{3}{*}{$\begin{array}{c}\text { Загаль- } \\
\text { ний } \\
\text { обсяг }\end{array}$} & \multicolumn{4}{|c|}{ аудиторних } & \\
\hline & & & \multirow[t]{2}{*}{ всього } & \multicolumn{3}{|c|}{ у тому числі } & \\
\hline & & & & лекц & семін & практ & \\
\hline 1. & $\begin{array}{l}\text { Інформатика як фундаментальна } \\
\text { системоутворююча наука }\end{array}$ & 18 & 14 & 4 & 4 & 6 & 4 \\
\hline 1.1 & Базові питання загальної інформатики & & 2 & - & 2 & - & \\
\hline 1.2 & $\begin{array}{l}\text { Програмно-прикладне забезпечення } \\
\text { інформаційних технологій }\end{array}$ & & 4 & 2 & - & 2 & \\
\hline 1.3. & $\begin{array}{l}\text { Системи прийняття рішень та автоматизова- } \\
\text { ні інформаційні системи }\end{array}$ & & 8 & 2 & 2 & 4 & \\
\hline 2. & $\begin{array}{l}\text { Методи інформатики в біологічних } \\
\text { дослідженнях }\end{array}$ & 70 & 60 & 14 & 20 & 26 & 10 \\
\hline 2.1 & $\begin{array}{l}\text { Сучасні інформаційні технології в біологіч- } \\
\text { ній галузі }\end{array}$ & & 4 & 2 & 2 & 4 & \\
\hline 2.2 & Біоінформатика та обчислювальна біологія & & 8 & 2 & 4 & 4 & \\
\hline 2.3 & Основи аналізу біологічних зображень & & 6 & 2 & 2 & 2 & \\
\hline 2.4 & Доказова медицина & & 6 & - & 2 & 4 & \\
\hline 2.5 & $\begin{array}{l}\text { Інформаційно-методологічні аспекти біо- } \\
\text { логічної діагностики }\end{array}$ & & 6 & 2 & 2 & 2 & \\
\hline 2.6 & $\begin{array}{l}\text { Інформаційно-алгоритмічні основи діагнос- } \\
\text { тичних досліджень }\end{array}$ & & 6 & 2 & 2 & 2 & \\
\hline 2.7 & Інформаційні технології в управлінні & & 10 & 2 & 4 & 4 & \\
\hline 2.8 & Інформаційні технології у генетиці & & 8 & 2 & 2 & 4 & \\
\hline 3. & Оброблення й аналіз даних досліджень & 66 & 56 & 10 & 14 & 32 & 10 \\
\hline 3.1 & Методи статистичного аналізу даних & & 6 & 2 & 2 & 4 & \\
\hline 3.2 & $\begin{array}{l}\text { Елементи теорії ймовірностей і математич- } \\
\text { ної статистики }\end{array}$ & & 12 & 2 & 2 & 8 & \\
\hline 3.3 & $\begin{array}{l}\text { Методи оброблення біологічних сигналів і } \\
\text { даних }\end{array}$ & & 6 & 2 & 2 & 4 & \\
\hline 3.4 & Математичні основи аналізу даних & & 6 & 2 & - & 4 & \\
\hline 3.5 & $\begin{array}{l}\text { Комп’ютерний аналіз та інтерпретації біо- } \\
\text { логічних даних }\end{array}$ & & 10 & 2 & 4 & 6 & \\
\hline 3.6 & $\begin{array}{l}\text { Прикладні аспекти застосування методів } \\
\text { аналізу даних }\end{array}$ & & 10 & - & 4 & 6 & \\
\hline 4. & Біологічна кібернетика & 56 & 50 & 14 & 22 & 14 & 6 \\
\hline 4.1 & Біологічні системи як об’єкт дослідження & & 6 & 2 & 4 & - & \\
\hline 4.2 & $\begin{array}{l}\text { Методи та системи оптимізації у біологіч- } \\
\text { них дослідженнях }\end{array}$ & & 10 & 2 & 4 & 4 & \\
\hline 4.3 & $\begin{array}{l}\text { Управління на різних рівнях організації } \\
\text { системи }\end{array}$ & & 10 & 4 & 4 & 4 & \\
\hline
\end{tabular}




\begin{tabular}{|c|c|c|c|c|c|c|c|}
\hline \multirow{4}{*}{$\begin{array}{l}\text { № } \\
\text { 3/ח }\end{array}$} & \multirow[t]{4}{*}{ Модуль, курс } & \multicolumn{5}{|c|}{ Кількість годин } & \multirow{4}{*}{$\begin{array}{l}\text { Само- } \\
\text { стійна } \\
\text { робота }\end{array}$} \\
\hline & & \multirow{3}{*}{$\begin{array}{c}\text { Загаль- } \\
\text { ний } \\
\text { обсяг }\end{array}$} & \multicolumn{4}{|c|}{ аудиторних } & \\
\hline & & & \multirow[t]{2}{*}{ Всього } & \multicolumn{3}{|c|}{ у тому числі } & \\
\hline & & & & лекц & семін & практ & \\
\hline 4.4 & Кібернетичне прогнозування в біології & & 8 & 2 & 4 & 2 & \\
\hline 4.5 & Геоінформаційні системи & & 4 & 2 & 2 & - & \\
\hline 4.6 & Сучасні кібернетичні технології у біології & & 10 & 2 & 4 & 4 & \\
\hline 5. & Математичне моделювання & 44 & 38 & 8 & 8 & 22 & 6 \\
\hline 5.1 & $\begin{array}{l}\text { Основи математичного та комп’ютерного } \\
\text { моделювання }\end{array}$ & & 10 & 2 & 2 & 6 & \\
\hline 5.2 & $\begin{array}{l}\text { Методологія та програмно-математичне } \\
\text { забезпечення }\end{array}$ & & 10 & 2 & 2 & 6 & \\
\hline 5.3 & $\begin{array}{l}\text { Синергетичні принципи дослідження } \\
\text { біологічних систем }\end{array}$ & & 8 & 2 & 2 & 4 & \\
\hline 5.4 & Моделювання процесів у відкритих системах & & 10 & 2 & 2 & 6 & \\
\hline 6. & Телекомунікаційні технології & 28 & 22 & 6 & 6 & 10 & 6 \\
\hline 6.1 & Телекомунікаційні мережі & & 6 & 2 & 2 & 2 & \\
\hline 6.2 & $\begin{array}{l}\text { Технологічні питання передавання } \\
\text { біологічної інформації }\end{array}$ & & 6 & 2 & - & 4 & \\
\hline 6.3 & Телемедицина & & 2 & - & 2 & 2 & \\
\hline 6.4 & Захист інформації у розподілених мережах & & 6 & 2 & 2 & 2 & \\
\hline 7. & Сучасні інформаційні технології в освіті & 30 & 26 & 4 & 8 & 14 & 4 \\
\hline 7.1 & Теоретичні засади інформатизації освіти & & 6 & 2 & 2 & 2 & \\
\hline 7.2 & Автоматизовані навчаючі системи & & 6 & - & 2 & 4 & \\
\hline 7.3 & Контроль знань в освіті & & 8 & 2 & 2 & 4 & \\
\hline 7.4 & Інформаційні аспекти дистанційної освіти & & 6 & - & 2 & 4 & \\
\hline 8. & $\begin{array}{l}\text { Новітні напрями біологічної та медичної } \\
\text { інформатики }\end{array}$ & 38 & 34 & 10 & 10 & 14 & 4 \\
\hline 8.1 & Інформаційні аспекти мобільної медицини & & 8 & 2 & 2 & 4 & \\
\hline 8.2 & $\begin{array}{l}\text { Інформаційні основи персоналізованої } \\
\text { медицини }\end{array}$ & & 10 & 2 & 4 & 4 & \\
\hline 8.3 & Роботизована медицина & & 4 & 2 & - & 2 & \\
\hline 8.4 & Інформаційні аспекти симуляційної медицини & & 8 & 2 & 2 & 4 & \\
\hline 8.5 & Інформаційні аспекти наномедицини & & 4 & 2 & 2 & - & \\
\hline & Контроль знань & 10 & & & 10 & & \\
\hline & Загалом & 360 & 310 & 70 & 102 & 138 & 50 \\
\hline
\end{tabular}




\section{НАВЧАЛЬНИЙ ПЛАН}

\section{дисципліни «Медична та біологічна інформатика і кібернетика»}

для здобувачів вищої освіти ступеня доктора філософії

(очна вечірня форма навчання)

09 - Біологія, спеціальність 091 - Біологія

\begin{tabular}{|c|c|c|c|c|c|c|c|}
\hline \multirow{4}{*}{$\begin{array}{l}\text { № } \\
\text { 3/П }\end{array}$} & \multirow[t]{4}{*}{ Модуль, курс } & \multicolumn{5}{|c|}{ Кількість годин } & \multirow{4}{*}{$\begin{array}{l}\text { Само- } \\
\text { стійна } \\
\text { робота }\end{array}$} \\
\hline & & \multirow{3}{*}{$\begin{array}{c}\text { Загаль- } \\
\text { ний } \\
\text { обсяг }\end{array}$} & \multicolumn{4}{|c|}{ аудиторних } & \\
\hline & & & \multirow[t]{2}{*}{ всього } & \multicolumn{3}{|c|}{ у тому числі } & \\
\hline & & & & лекц & семін & практ & \\
\hline 1. & $\begin{array}{l}\text { Інформатика як фундаментальна систе- } \\
\text { моутворююча наука }\end{array}$ & 20 & 10 & 4 & 2 & 4 & 10 \\
\hline 1.1 & Базові питання загальної інформатики & & 2 & - & 2 & - & \\
\hline 1.2 & $\begin{array}{l}\text { Програмно-прикладне забезпечення } \\
\text { інформаційних технологій }\end{array}$ & & 4 & 2 & - & 2 & \\
\hline 1.3. & $\begin{array}{l}\text { Системи прийняття рішень та } \\
\text { автоматизовані інформаційні системи }\end{array}$ & & 4 & 2 & - & 2 & \\
\hline 2. & $\begin{array}{l}\text { Методи інформатики в біологічних } \\
\text { дослідженнях }\end{array}$ & 70 & 46 & 14 & 12 & 20 & 24 \\
\hline 2.1 & $\begin{array}{l}\text { Сучасні інформаційні технології } \\
\text { в біологічній галузі }\end{array}$ & & 6 & 2 & 2 & 2 & \\
\hline 2.2 & Біоінформатика та обчислювальна біологія & & 8 & 2 & 2 & 4 & \\
\hline 2.3 & Основи аналізу біологічних зображень & & 6 & 2 & 2 & 2 & \\
\hline 2.4 & Доказова медицина & & 4 & - & - & 4 & \\
\hline 2.5 & $\begin{array}{l}\text { Інформаційно-методологічні аспекти } \\
\text { біологічної діагностики }\end{array}$ & & 6 & 2 & 2 & 2 & \\
\hline 2.6 & $\begin{array}{l}\text { Інформаційно-алгоритмічні основи } \\
\text { діагностичних досліджень }\end{array}$ & & 6 & 2 & 2 & 2 & \\
\hline 2.7 & Інформаційні технології в управлінні & & 6 & 2 & 2 & 2 & \\
\hline 2.8 & Інформаційні технології у генетиці & & 4 & 2 & - & 2 & \\
\hline 3. & Оброблення й аналіз даних досліджень & 64 & 40 & 10 & 6 & 24 & 24 \\
\hline 3.1 & Методи статистичного аналізу даних & & 6 & 2 & - & 4 & \\
\hline 3.2 & $\begin{array}{l}\text { Елементи теорії ймовірностей і } \\
\text { математичної статистики }\end{array}$ & & 6 & 2 & 2 & 2 & \\
\hline 3.3 & $\begin{array}{l}\text { Методи оброблення біологічних сигналів і } \\
\text { даних }\end{array}$ & & 6 & 2 & - & 4 & \\
\hline 3.4 & Математичні основи аналізу даних & & 6 & 2 & - & 4 & \\
\hline 3.5 & $\begin{array}{l}\text { Комп’ютерний аналіз та інтерпретації біо- } \\
\text { логічних даних }\end{array}$ & & 10 & 2 & 2 & 6 & \\
\hline 3.6 & $\begin{array}{l}\text { Прикладні аспекти застосування методів } \\
\text { аналізу даних }\end{array}$ & & 6 & - & 2 & 4 & \\
\hline 4. & Біологічна кібернетика & 54 & 40 & 12 & 14 & 14 & 14 \\
\hline 4.1 & Біологічні системи як об’єкт дослідження & & 6 & 2 & 4 & - & \\
\hline 4.2 & $\begin{array}{l}\text { Методи та системи оптимізації } \\
\text { у біологічних дослідженнях }\end{array}$ & & 8 & 2 & 2 & 4 & \\
\hline 4.3 & $\begin{array}{l}\text { Управління на різних рівнях організації } \\
\text { системи }\end{array}$ & & 8 & 2 & 2 & 4 & \\
\hline
\end{tabular}




\begin{tabular}{|c|c|c|c|c|c|c|c|}
\hline \multirow{4}{*}{$\begin{array}{l}\text { № } \\
\text { 3/ח }\end{array}$} & \multirow[t]{4}{*}{ Модуль, курс } & \multicolumn{5}{|c|}{ Кількість годин } & \multirow{4}{*}{$\begin{array}{l}\text { Само- } \\
\text { стійна } \\
\text { робота }\end{array}$} \\
\hline & & \multirow{3}{*}{$\begin{array}{c}\text { Загаль- } \\
\text { ний } \\
\text { обсяг }\end{array}$} & \multicolumn{4}{|c|}{ аудиторних } & \\
\hline & & & \multirow[t]{2}{*}{ Всього } & \multicolumn{3}{|c|}{ у тому числі } & \\
\hline & & & & лекц & семін & практ & \\
\hline 4.4 & Кібернетичне прогнозування в біології & & 6 & 2 & 2 & 2 & \\
\hline 4.5 & Геоінформаційні системи & & 2 & 2 & - & - & \\
\hline 4.6 & Сучасні кібернетичні технології у біології & & 10 & 2 & 4 & 4 & \\
\hline 5. & Математичне моделювання & 44 & 30 & 8 & 6 & 16 & 14 \\
\hline 5.1 & $\begin{array}{l}\text { Основи математичного та комп’ютерного } \\
\text { моделювання }\end{array}$ & & 6 & 2 & - & 4 & \\
\hline 5.2 & $\begin{array}{l}\text { Методологія та програмно-математичне за- } \\
\text { безпечення }\end{array}$ & & 8 & 2 & 2 & 4 & \\
\hline 5.3 & $\begin{array}{l}\text { Синергетичні принципи дослідження біо- } \\
\text { логічних систем }\end{array}$ & & 6 & 2 & 2 & 2 & \\
\hline 5.4 & Моделювання процесів у відкритих системах & & 10 & 2 & 2 & 6 & \\
\hline 6. & Телекомунікаційні технології & 32 & 18 & 6 & 4 & 8 & 14 \\
\hline 6.1 & Телекомунікаційні мережі & & 4 & 2 & 4 & 2 & \\
\hline 6.2 & $\begin{array}{l}\text { Технологічні питання передавання } \\
\text { біологічної інформації }\end{array}$ & & 4 & 2 & - & 2 & \\
\hline 6.3 & Телемедицина & & 4 & - & 2 & 2 & \\
\hline 6.4 & Захист інформації у розподілених мережах & & 4 & 2 & - & 2 & \\
\hline 7. & Сучасні інформаційні технології в освіті & 30 & 20 & 4 & 6 & 10 & 10 \\
\hline 7.1 & Теоретичні засади інформатизації освіти & & 4 & 2 & 2 & - & \\
\hline 7.2 & Автоматизовані навчаючі системи & & 4 & - & 2 & 2 & \\
\hline 7.3 & Контроль знань в освіті & & 6 & 2 & - & 4 & \\
\hline 7.4 & Інформаційні аспекти дистанційної освіти & & 6 & - & 2 & 4 & \\
\hline 8. & $\begin{array}{l}\text { Новітні напрями біологічної та медичної } \\
\text { інформатики }\end{array}$ & 36 & 26 & 10 & 8 & 8 & 10 \\
\hline 8.1 & Інформаційні аспекти мобільної медицини & & 6 & 2 & 2 & 2 & \\
\hline 8.2 & $\begin{array}{l}\text { Інформаційні основи персоналізованої } \\
\text { медицини }\end{array}$ & & 6 & 2 & 2 & 2 & \\
\hline 8.3 & Роботизована медицина & & 4 & 2 & - & 2 & \\
\hline 8.4 & Інформаційні аспекти симуляційної медицини & & 6 & 2 & 2 & 2 & \\
\hline 8.5 & Інформаційні аспекти наномедицини & & 4 & 2 & 2 & - & \\
\hline & Контроль знань & 10 & & & 10 & & \\
\hline & Загалом & 360 & 240 & 68 & 68 & 104 & 120 \\
\hline
\end{tabular}




\section{НАВЧАЛЬНИЙ ПЛАН}

з дисципліни «Медична та біологічна інформатика і кібернетика»

для здобувачів вищої освіти ступеня доктора філософії

(заочна форма навчання)

09 - Біологія, спеціальність 091 - Біологія

\begin{tabular}{|c|c|c|c|c|c|c|c|}
\hline \multirow{4}{*}{$\begin{array}{l}\text { № } \\
\text { 3/ח }\end{array}$} & \multirow[t]{4}{*}{ Модуль, курс } & \multicolumn{5}{|c|}{ Кількість годин } & \multirow{4}{*}{$\begin{array}{l}\text { Само- } \\
\text { стійна } \\
\text { робота }\end{array}$} \\
\hline & & \multirow{3}{*}{$\begin{array}{c}\text { Загаль- } \\
\text { ний } \\
\text { обсяг }\end{array}$} & \multicolumn{4}{|c|}{ аудиторних } & \\
\hline & & & \multirow[t]{2}{*}{ ВСЬОГО } & \multicolumn{3}{|c|}{ у тому числі } & \\
\hline & & & & лекц & семін & практ & \\
\hline 1. & $\begin{array}{l}\text { Інформатика як фундаментальна систе- } \\
\text { моутворююча наука }\end{array}$ & 26 & 6 & 4 & 2 & - & 20 \\
\hline 1.1 & Базові питання загальної інформатики & & 2 & - & 2 & - & \\
\hline 1.2 & $\begin{array}{l}\text { Програмно-прикладне забезпечення інфор- } \\
\text { маційних технологій }\end{array}$ & & 2 & 2 & - & - & \\
\hline 1.3. & $\begin{array}{l}\text { Системи прийняття рішень та автоматизова- } \\
\text { ні інформаційні системи }\end{array}$ & & 2 & 2 & - & - & \\
\hline 2. & $\begin{array}{l}\text { Методи інформатики в біологічних до- } \\
\text { слідженнях }\end{array}$ & 70 & 22 & 8 & 4 & 10 & 48 \\
\hline 2.1 & $\begin{array}{l}\text { Сучасні інформаційні технології } \\
\text { в біологічній галузі }\end{array}$ & & 2 & 2 & - & - & \\
\hline 2.2 & Біоінформатика та обчислювальна біологія & & 4 & - & 2 & 2 & \\
\hline 2.3 & Основи аналізу біологічних зображень & & 2 & - & - & 2 & \\
\hline 2.4 & Доказова медицина & & 2 & - & - & 2 & \\
\hline 2.5 & $\begin{array}{l}\text { Інформаційно-методологічні аспекти } \\
\text { біологічної діагностики }\end{array}$ & & 2 & 2 & - & - & \\
\hline 2.6 & $\begin{array}{l}\text { Інформаційно-алгоритмічні основи } \\
\text { діагностичних досліджень }\end{array}$ & & 4 & 2 & - & 2 & \\
\hline 2.7 & Інформаційні технології в управлінні & & 4 & - & 2 & 2 & \\
\hline 2.8 & Інформаційні технології у генетиці & & 2 & 2 & - & - & \\
\hline 3. & Оброблення й аналіз даних досліджень & 66 & 18 & 6 & - & 12 & 48 \\
\hline 3.1 & Методи статистичного аналізу даних & & 2 & - & - & 2 & \\
\hline 3.2 & $\begin{array}{l}\text { Елементи теорії ймовірностей і } \\
\text { математичної статистики }\end{array}$ & & 4 & 2 & - & 2 & \\
\hline 3.3 & $\begin{array}{l}\text { Методи оброблення біологічних } \\
\text { сигналів і даних }\end{array}$ & & 2 & - & - & 2 & \\
\hline 3.4 & Математичні основи аналізу даних & & 4 & 2 & - & 2 & \\
\hline 3.5 & $\begin{array}{l}\text { Комп’ютерний аналіз та інтерпретації біо- } \\
\text { логічних даних }\end{array}$ & & 4 & 2 & - & 2 & \\
\hline 3.6 & $\begin{array}{l}\text { Прикладні аспекти застосування методів } \\
\text { аналізу даних }\end{array}$ & & 2 & - & - & 2 & \\
\hline 4. & Біологічна кібернетика & 54 & 26 & 12 & 6 & 8 & 28 \\
\hline 4.1 & Біологічні системи як об’єкт дослідження & & 2 & 2 & - & - & \\
\hline 4.2 & $\begin{array}{l}\text { Методи та системи оптимізації у біологічних } \\
\text { дослідженнях }\end{array}$ & & 4 & 2 & - & 2 & \\
\hline 4.3 & $\begin{array}{l}\text { Управління на різних рівнях організації } \\
\text { системи }\end{array}$ & & 6 & 2 & 2 & 2 & \\
\hline
\end{tabular}




\begin{tabular}{|c|c|c|c|c|c|c|c|}
\hline \multirow{4}{*}{$\begin{array}{l}\text { № } \\
\text { 3/ח }\end{array}$} & \multirow[t]{4}{*}{ Модуль, курс } & \multicolumn{5}{|c|}{ Кількість годин } & \multirow{4}{*}{$\begin{array}{l}\text { Само- } \\
\text { стійна } \\
\text { робота }\end{array}$} \\
\hline & & \multirow{3}{*}{$\begin{array}{c}\text { Загаль- } \\
\text { ний } \\
\text { обсяг }\end{array}$} & \multicolumn{4}{|c|}{ аудиторних } & \\
\hline & & & \multirow[t]{2}{*}{ Всього } & \multicolumn{3}{|c|}{ у тому числі } & \\
\hline & & & & лекц & семін & практ & \\
\hline 4.4 & Кібернетичне прогнозування в біології & & 6 & 2 & 2 & 2 & \\
\hline 4.5 & Геоінформаційні системи & & 2 & 2 & - & - & \\
\hline 4.6 & Сучасні кібернетичні технології у біології & & 6 & 2 & 2 & 2 & \\
\hline 5. & Математичне моделювання & 42 & 14 & 6 & 2 & 6 & 28 \\
\hline 5.1 & $\begin{array}{l}\text { Основи математичного та комп’ютерного } \\
\text { моделювання }\end{array}$ & & 4 & 2 & - & 2 & \\
\hline 5.2 & $\begin{array}{l}\text { Методологія та програмно-математичне } \\
\text { забезпечення }\end{array}$ & & 4 & - & 2 & 2 & \\
\hline 5.3 & $\begin{array}{l}\text { Синергетичні принципи дослідження } \\
\text { біологічних систем }\end{array}$ & & 4 & 2 & - & - & \\
\hline 5.4 & Моделювання процесів у відкритих системах & & 4 & 2 & - & 2 & \\
\hline 6. & Телекомунікаційні технології & 34 & 6 & 2 & 2 & 2 & 28 \\
\hline 6.1 & Телекомунікаційні мережі & & 2 & - & 2 & - & \\
\hline 6.2 & $\begin{array}{l}\text { Технологічні питання передавання } \\
\text { біологічної інформації }\end{array}$ & & 2 & - & - & 2 & \\
\hline 6.3 & Телемедицина & & - & - & - & - & \\
\hline 6.4 & Захист інформації у розподілених мережах & & 2 & 2 & - & - & \\
\hline 7. & Сучасні інформаційні технології в освіті & 28 & 8 & 2 & 2 & 4 & 20 \\
\hline 7.1 & Теоретичні засади інформатизації освіти & & 2 & 2 & - & - & \\
\hline 7.2 & Автоматизовані навчаючі системи & & 2 & - & 2 & - & \\
\hline 7.3 & Контроль знань в освіті & & 2 & - & - & 2 & \\
\hline 7.4 & Інформаційні аспекти дистанційної освіти & & 2 & - & - & 2 & \\
\hline 8. & $\begin{array}{l}\text { Новітні напрями біологічної та медичної } \\
\text { інформатики }\end{array}$ & 30 & 10 & 4 & 4 & 2 & 20 \\
\hline 8.1 & Інформаційні аспекти мобільної медицини & & 2 & 2 & - & - & \\
\hline 8.2 & $\begin{array}{l}\text { Інформаційні основи персоналізованої } \\
\text { медицини }\end{array}$ & & 2 & 2 & - & - & \\
\hline 8.3 & Роботизована медицина & & 2 & - & 2 & - & \\
\hline 8.4 & Інформаційні аспекти симуляційної медицини & & 2 & - & - & 2 & \\
\hline 8.5 & Інформаційні аспекти наномедицини & & 2 & - & 2 & - & \\
\hline & Контроль знань & 10 & & & 10 & & \\
\hline & Загалом & 360 & 120 & 44 & 32 & 44 & 240 \\
\hline
\end{tabular}




\title{
НАВЧАЛЬНО-МЕТОДИЧНЕ ЗАБЕЗПЕЧЕННЯ САМОСТІЙНОЇ РОБОТИ
}

\author{
3 дисципліни «Медична та біологічна інформатика і кібернетика» \\ для здобувачів вищої освіти ступеня доктора філософії \\ (очна (денна, вечірня), заочна форми навчання) \\ за спеціальностями: 224 - Технології медичної діагностики та лікування, \\ 091 - Біологія \\ Тривалість навчання: 2,0 міс. (12 кредитів, 360 год.)
}

\section{Форми та види організації самостійної роботи (СР)}

1. Підготовка до практичних занять з використанням лекцій, основної та додаткової літератури, а також навчально-методичних розробок кафедри.

2. Самостійне освоєння окремих тем навчального плану, що не мають місця на практичних заняттях. У цій роботі здобувачі використовують доступну навчальну літературу, Інтернет-ресурси та допоміжну літературу, методичні матеріали, розроблені кафедрою.

3. Самостійна робота на практичному занятті під контролем викладача здійснюється відповідно до методичних рекомендацій кафедри та включає:

а. рішення тестових завдань і аналіз конкретних ситуацій із різних розділів медичної та біологічної інформатики і кібернетики;

б. роботу з комп'ютерними навчальними програмами;

в. роботу з доступними медичними інформаційними системами $3 \mathrm{O}$ і органів управління охороною здоров'я;

г. проведення математичного оброблення медичних/біологічних даних із застосуванням різних спеціалізованих програмних продуктів;

д. роботу з базами та банками даних і знань.

4. Робота в комп’ютерному класі за навчальною програмою - закріплює та поглиблює знання здобувачів із різних розділів дисципліни, розвиває логічне мислення.

5. Інформаційний огляд ресурсів Інтернет за різними напрямами дисципліни. Під керівництвом викладача здобувачі вчаться вести самостійний пошук необхідних джерел інформації в Інтернеті, опановувати навики критичного читання, вміння готувати реферативні роботи. Реферативні доповіді та повідомлення здобувачів можуть заслуховуватись як на практичному занятті, так і на заходах товариства молодих учених або на наукових конференціях.

6. Виконання фрагмента науково-дослідної роботи включає: підбір літератури, розроблення бібліографічних покажчиків за тематикою наукових досліджень, освоєння роботи з сучасними медичними системами 3О3, програмами для комп’ютерного моделювання, участь у статистичній обробці результатів дослідження. Наведений тип СР розвиває навики роботи з науковою літературою, вміння конспектувати, цитувати, реферувати, складати бібліографію та тези, а також сприяє розвитку навиків наукової роботи, розширенню знань з різних розділів дисципліни, їх систематизації та аналізу.

7. Підготовка презентацій і доповідей, участь у наукових конференціях, зокрема кафедри. Пропонований тип СР вчить користуватися посібниками, монографічними виданнями, журнальними статтями, дає можливість навчитися виступати перед аудиторією, дискутувати, відповідати на поставлені запитання, сприяє глибшому пізнанню окремих питань дисципліни. Вчить здобувачів викладати матеріал із аналізом і оцінкою фактів, аргументованою критикою теоретичних положень, розвиває вміння виділяти головне, істотне, а також навчає принципам інтерпретації та систематизації наукових досліджень.

8. Кожне заняття проводиться відповідно до методичної розробки, що включає самостійну роботу здобувачів. 


\section{КОНТРОЛЬ ЗНАНЬ}

з дисципліни «Медична та біологічна інформатика і кібернетика»

для здобувачів вищої освіти ступеня доктора філософії

(очна (денна, вечірня), заочна форми навчання)

за спеціальностями: 224 - Технології медичної діагностики та лікування, 091 - Біологія

Тривалість навчання: 2,0 міс. (12 кредитів, 360 год.)

\section{1. Характеристика та технологія проведення поточного і проміжного контролю}

Освітня програма та навчальний план підготовки здобувачів передбачають поточний і проміжний контроль знань, а також спеціальний контроль виживання знань. Вивчення дисципліни завершується здаванням заліку. Для контролю знань застосовується бально-рейтингова система. Проміжний контроль проводиться після вивчення кожного модулю дисципліни у вигляді підсумкової самостійної роботи 3 використанням комп’ютерних технологій та усної співбесіди.

Види та форми поточного контролю знань на семінарських/практичних заняттях:

- вхідний контроль - тестування на початку заняття, що дозволяє провести перевірку знань і вмінь здобувачів, необхідних для розбору теми заняття;

- рубіжний контроль — перевірка окремих розділів/тем і навиків, отриманих у ході заняття. Проводиться у формі оцінювання рівня засвоєння вмінь при виконань завдань за допомогою комп’ютера;

- вихідний контроль - тестування в кінці заняття для перевірки знань і вмінь, засвоєних на занятті;

- контроль виживання знань - тестування на початку кожного модулю.

\section{2. Технологія проведення підсумкового контролю знань (заліку)}

Залік проводиться на останньому занятті дисципліни з застосуванням бально-рейтингової системи. До здавання заліку допускаються здобувачі, які не мають академічної заборгованості з дисципліни. Здобувачі попередньо мають можливість ознайомитись з переліком питань для підготовки до заліку в інформаційних матеріалах кафедри.

Залік із дисципліни проводиться в 2 етапи: 1) тестовий контроль за варіантами (50 питань); 2) перевірка практичних умінь та компетентностей при виконанні завдань на комп’ютері.

\section{3. Оціночні ресурси для поточного та проміжного контролю знань}

Для контролю знань застосовується бально-рейтингова система за 100-бальною шкалою відповідно до загальноприйнятих критеріїв (табл. 1).

Поточний контроль знань на семінарському/практичному занятті проводяться у вигляді тестування, в т.ч. комп’ютерного, та оцінювання якості виконання завдань.

Вхідний контроль дозволяє оцінити початковий рівень знань і вмінь здобувачів, необхідних для засвоєння теми заняття.

Рубіжний контроль - засвоєння знань і навиків, отриманих протягом проведення заняття. Дозволяє оцінити засвоєння знань і вмінь при виконанні певних завдань.

Вихідний контроль - здійснюється для забезпечення оцінювання засвоєних знань і вмінь при завершенні заняття.

Контроль виживання знань проводиться на першому занятті кожного модулю у вигляді тестування.

Проміжний контроль проводиться на останньому занятті кожного модулю в 2 етапи: 1) комп’ютерний контроль виконання завдань; 2) співбесіда з оцінюванням засвоєння теоретичних розділів модулю. До проходження проміжного контролю допускається здобувач при відсутності пропусків занять без поважної причини; в іншому випадку пропущені заняття повинні бути попередньо відпрацьовані.

\section{4. Оціночні ресурси для підсумкового контролю знань (заліку)}

\section{Методика проведення підсумкового контролю знань (заліку)}

Позитивна оцінка на заліку є обов'язковою умовою успішного завершення навчання з дисципліни.

Підсумкова оцінка з дисципліни обчислюється як середня арифметична двох величин: оцінок успішності протягом навчання та оцінки на заліку. 
Критерії підсумкового оцінювання грунтуються на принципах оцінювання в системі ECTS. Використовується внутрішня система оцінювання знань, що забезпечує вдосконалення принципів підготовки здобувачів (табл. 1).

Таблиця 1

Система внутрішнього оцінювання знань, умінь, компетентностей здобувача

\begin{tabular}{|c|c|}
\hline Характеристика відповіді & Бали \\
\hline $\begin{array}{l}\text { Надано повну, розгорнуту відповідь на поставлене запитання, показана сукупність усвідомлених } \\
\text { знань про об’єкт, що виявляється у вільному орієнтуванні поняттями, вмінні виділити суттєві } \\
\text { ознаки, причинно-наслідкові зв’язки. } \\
\text { Знання про об’єкт демонструються на тлі розуміння його в системі даної науки, між - та тран- } \\
\text { сдисциплінарних зв’язків. Відповідь формулюється в наукових термінах, викладених літератур- } \\
\text { ною мовою. Відповідь характеризується формальною логікою, має достатній доказовий ресурс, } \\
\text { демонструє авторську позицію здобувача }\end{array}$ & $100-96$ \\
\hline $\begin{array}{l}\text { Надано повну розгорнуту відповідь на поставлене запитання, показана сукупність усвідомлених } \\
\text { знань про об’єкт, доказово розкрито основні положення теми; у відповіді простежується чітка } \\
\text { структура, логічна послідовність, що відображає сутність понять, теорій, явищ. Знання про об’єкт } \\
\text { демонструються на тлі розуміння процесів у системі даної науки та міждисциплінарних зв’язків. } \\
\text { Відповідь викладено літературною мовою в коректних наукових термінах. Можуть бути допуще- } \\
\text { ні недоліки у визначенні понять, що виправляються здобувачем самостійно в процесі відповіді }\end{array}$ & $95-91$ \\
\hline $\begin{array}{l}\text { Надано повну розгорнуту відповідь на поставлене запитання, доказово розкриті основні поло- } \\
\text { ження теми; у відповіді простежується чітка структура, логічна послідовність, що відображає } \\
\text { сутність понять, теорій, явищ. } \\
\text { Відповідь викладено літературною мовою в термінах науки. У відповіді виявлені недоліки, ви- } \\
\text { правлені здобувачем за допомогою викладача }\end{array}$ & $90-86$ \\
\hline $\begin{array}{l}\text { Надано повну розгорнуту відповідь на поставлене запитання, показано вміння виділити суттєві } \\
\text { та несуттєві ознаки, причинно-наслідкові зв’язки. Відповідь чітко структурована, логічна, викла- } \\
\text { дена літературною мовою в термінах науки. Можуть бути виявлені недоліки або незначні помил- } \\
\text { ки, що недостатньо виправляються здобувачем навіть за допомогою викладача }\end{array}$ & $85-81$ \\
\hline $\begin{array}{l}\text { Надано повну розгорнуту відповідь на поставлене запитання, показано вміння виділити суттєві } \\
\text { та несуттєві ознаки, причинно-наслідкові зв’язки. Відповідь чітко структурована, логічна, ви- } \\
\text { кладена в термінах науки. Проте допущена значна кількість невеликих помилок або допущено } \\
\text { суттєвіші недоліки, виправлені здобувачем за допомогою викладача }\end{array}$ & $80-76$ \\
\hline $\begin{array}{l}\text { Надано повну, але недостатньо послідовну відповідь на поставлене питання. Показано вміння } \\
\text { виділити суттєві та несуттєві ознаки, причинно-наслідкові зв’язки. Відповідь логічна, викладена } \\
\text { в термінах науки. Виявлено поодинокі помилки у визначенні основних понять, що здобувач не } \\
\text { може виправити самостійно. }\end{array}$ & $75-71$ \\
\hline $\begin{array}{l}\text { Надано недостатньо повну та недостатньо розгорнуту відповідь. Допущено помилки в розкритті } \\
\text { понять, вживанні термінів. Здобувач не здатен самостійно виділити суттєві та несуттєві ознаки, } \\
\text { причинно-наслідкові зв’язки. Здобувач може конкретизувати узагальнені знання, довівши на при- } \\
\text { кладах їх основні положення тільки за допомогою викладача. Мовне оформлення вимагає корекції }\end{array}$ & $70-66$ \\
\hline $\begin{array}{l}\text { Надано неповну відповідь, логіка та послідовність викладу мають суттєві порушення. Допущено } \\
\text { грубі помилки при визначенні сутності розкритих понять, теорій, явищ, внаслідок нерозуміння } \\
\text { здобувачем їх істотних і несуттєвих ознак і зв’язків. У відповіді відсутні висновки. Вміння роз- } \\
\text { крити конкретні прояви узагальнених знань не показано. Мовне оформлення вимагає корекції }\end{array}$ & $65-61$ \\
\hline $\begin{array}{l}\text { Надано неповну відповідь. Існує нелогічність викладу. Виявлено значну кількість істотних по- } \\
\text { милок у визначенні термінів, понять, характеристиці фактів, явищ. У відповіді відсутні висно- } \\
\text { вки. При відповіді на додаткові питання здобувач починає розуміти зв’язок між знаннями тільки } \\
\text { після підказки викладача }\end{array}$ & $60-56$ \\
\hline
\end{tabular}


Надано неповну відповідь, що відображає розрізнені знання з істотними помилками у визначеннях. Присутні фрагментарність, нелогічність викладу. Відсутнє розуміння зв’язку даного поняття, теорії, явища з іншими об’єктами дисципліни. Відсутні висновки, конкретизація та доказовість.

Додаткові й уточнюючі питання викладача не призводять до корекції відповіді здобувача не тільки на поставлене запитання, а й на інші питання дисципліни

\begin{tabular}{|l|c|}
\hline Не отримано відповіді по базових питаннях дисципліни & $50-45$ \\
\hline Відмова від відповіді & $\begin{array}{c}\text { Мен- } \\
\text { ше } 45\end{array}$ \\
\hline Присутність на занятті & \\
\hline Відсутність на занятті & \\
\hline
\end{tabular}




\section{ПЛАНОВІ РЕЗУЛЬТАТИ НАВЧАННЯ}

\section{з дисципліни «Медична та біологічна інформатика і кібернетика»}

для здобувачів вищої освіти ступеня доктора філософії (очна (денна, вечірня), заочна форми навчання) за спеціальностями: 224 - Технології медичної діагностики та лікування, 091 - Біологія

Тривалість навчання: 2,0 міс. (12 кредитів, 360 год.)

\section{Перелік компетентностей здобувача вищої освіти ступеня доктора філософії, що формуються в результаті освоєння дисципліни та їх кодування}

Для створення переліку використано рекомендації Ради Європи, Американської ради з вищої освіти (ACGME), американської ради з безперервного професійного розвитку лікарів (АССМЕ).

\section{1. Інтегральна компетентність}

Здатність розв'язувати складні завдання в сфері медичної та біологічної інформатики і кібернетики, управління та адміністрування або у процесі навчання, що передбачає проведення досліджень та/або здійснення інновацій, рішення завдань, що характеризуються невизначеністю умов і вимог.

2. Загальні лікарські компетентності (для підготовки здобувачів для всіх лікарських спеціальностей):

ЛК-1 - догляд за пацієнтами;

ЛК-2 - володіння медичними знаннями;

ЛК-3 — навчання та безперервний професійний розвиток (БПР) на основі практики;

ЛК-4 - міжособистісне спілкування;

ЛК-5 - професіоналізм;

ЛК-6 - системна практика.

\section{3. Ключові компетентності}

\begin{tabular}{|c|l|c|}
\hline \multirow{2}{*}{ № 3/п } & \multicolumn{1}{|c|}{ Вид діяльності } & Кодування \\
\cline { 2 - 3 } & \multicolumn{1}{|c|}{ Освітня діяльність } & КО \\
\hline 1. & Витягати корисну інформацію з освітнього контенту & КО-1 \\
\hline 2. & Організовувати взаємозв'язок своїх знань, упорядковувати їх & КО-2 \\
\hline 3. & $\begin{array}{l}\text { Обгрунтовувати та організовувати особистісні прийоми вивчення предметної об- } \\
\text { ласті }\end{array}$ & КО-3 \\
\hline 4. & Вміти вирішувати проблеми при навчанні & КО-4 \\
\hline 5. & Забезпечувати самонавчання & КО-5 \\
\hline 6. & Забезпечувати структуризацію навчального матеріалу, створювати онтологію знань & КП \\
\hline & Питання пошуку необхідної інформації & КПБ-1 \\
\hline 1. & Здійснювати професійний пошук даних у різних базах & КПО-2 \\
\hline 2. & Обробляти інформацію з оточення & КПЕ-3 \\
\hline 3. & Здійснювати експертне оцінювання інформації & КПР-4 \\
\hline 4. & Обробляти інформацію з різних джерел & КП-5 \\
\hline 5. & Уміти працювати з документами та класифікувати їх & КI \\
\hline & Інтелектуальна діяльність & КІО-1 \\
\hline 1. & Обгрунтовувати взаємозв’язок минулих і поточних подій, явищ \\
\hline 2. & $\begin{array}{l}\text { Критично ставитись до певного аспекту розвитку суспільства, рішення проблем, } \\
\text { виконання завдань }\end{array}$ & КІУ-3 \\
\hline 3. & Уміти протистояти непевності та труднощам & \multicolumn{1}{|c|}{} \\
\hline
\end{tabular}




\begin{tabular}{|c|l|c|}
\hline № 3/п & \multicolumn{1}{|c|}{ Вид діяльності } & Кодування \\
\hline 4. & Займати позицію в дискусіях і відстоювати свої думки & КІД-4 \\
\hline 5. & $\begin{array}{l}\text { Бачити важливість політичного й економічного оточення, в якому проходять на- } \\
\text { вчання та робота }\end{array}$ & КІП-5 \\
\hline 6. & $\begin{array}{l}\text { Оцінювати соціальні звички, пов'язані зі здоров’ям, споживанням, із навколишнім } \\
\text { середовищем }\end{array}$ & КІС-6 \\
\hline & Компетентності співробітництва & КС \\
\hline 1. & Уміти співробітничати та працювати в групі & КСГ-1 \\
\hline 2. & Приймати рішення, залагоджувати розбіжності та конфлікти & КСР-2 \\
\hline 3. & Уміти домовлятись & КСД-3 \\
\hline 4. & Уміти розробляти та виконувати контракти/угоди & КСК-4 \\
\hline & Входження в процесну діяльність & ВП \\
\hline 1. & Включатись у проект & ВПВП-1 \\
\hline 2. & Нести відповідальність за свої дії & ВПНВ-2 \\
\hline 3. & Входити до групи або колективу, робити свій внесок & ВПГ-3 \\
\hline 4. & Проявляти солідарність у відстоюванні колективного рішення & ВПС-4 \\
\hline 5. & Вміти організовувати свою роботу & ВПОР-5 \\
\hline 6. & Вміти користуватись обчислювальними та моделюючими приладами & ВПК-6 \\
\hline & Адаптації & А \\
\hline 1. & Уміти використовувати нові інформаційні технології та комунікації & АНІТ-1 \\
\hline 2. & Доводити гнучкість перед викликами швидких змін & АШ3-2 \\
\hline 3. & Показувати стійкість перед труднощами & АТ-3 \\
\hline 4. & Вміти знаходити нові рішення & АНТ-5 \\
\hline 5. & Адаптуватись до появи нових технологій & \\
\hline & & \multicolumn{1}{|c|}{} \\
\hline
\end{tabular}

\section{4. Загальні компетентності}

\begin{tabular}{|c|l|c|}
\hline № $\mathbf{3} / \mathbf{n}$ & \multicolumn{1}{|c|}{ Вид діяльності } & Кодування \\
\hline 1. & Здатність до абстрактного мислення, аналізу та синтезу & 3К-1 \\
\hline 2. & Здатність бути лідером & 3К-2 \\
\hline 3. & $\begin{array}{l}\text { Здатність удосконалювати та розвивати професійний, інтелектуальний і культур- } \\
\text { ний рівні }\end{array}$ & $3 \mathrm{~K}-3$ \\
\hline 4. & $\begin{array}{l}\text { Здатність генерувати нові ідеї та нестандартні підходи до їх реалізації (креатив- } \\
\text { ність) }\end{array}$ & $3 \mathrm{~K}-4$ \\
\hline 5. & $\begin{array}{l}\text { Здатність ініціювати, планувати та управляти змінами для вдосконалення існуючих } \\
\text { і розроблення нових інформаційних систем }\end{array}$ & $3 \mathrm{~K}-5$ \\
\hline 6. & Здатність до усного та письмового професійного спілкування іноземною мовою & 3К-6 \\
\hline 7. & $\begin{array}{l}\text { Здатність до раціональної критики та самокритики, конструктивної реакції на за- } \\
\text { уваження }\end{array}$ & 3К-7 \\
\hline 8. & $\begin{array}{l}\text { Здатність налагоджувати соціальну взаємодію, співробітництво, попереджати та } \\
\text { розв'язувати конфлікти }\end{array}$ & 3К-8 \\
\hline
\end{tabular}




\section{5. Професійні (фахові) компетентності}

\begin{tabular}{|c|c|c|}
\hline № $3 / \Pi$ & Вид діяльності & Кодування \\
\hline 1. & $\begin{array}{l}\text { Здатність вирішувати стандартні та нестандартні завдання професійної діяльності } \\
\text { з використанням інформаційних, бібліографічних ресурсів, медико-біологічної } \\
\text { термінології, інформаційно-комунікаційних технологій із урахуванням основних } \\
\text { вимог інформаційної безпеки }\end{array}$ & $\Phi \mathrm{K}-1$ \\
\hline 2. & $\begin{array}{l}\text { Здатність до застосування сучасних методик збору, збереження, оброблення, пере- } \\
\text { давання, статистичного аналізу інформації про показники здоров’я населення }\end{array}$ & $\Phi K-2$ \\
\hline 3. & $\begin{array}{l}\text { Здійснювати професійний аналіз медичної та біологічної інформації на основі } \\
\text { принципів доказової медицини }\end{array}$ & $\Phi \mathrm{T}-3$ \\
\hline 4. & Здатність до участі в проведенні наукових досліджень & $\Phi K-4$ \\
\hline 5. & $\begin{array}{l}\text { Здатність систематизувати й узагальнювати інформацію, готувати довідки та огля- } \\
\text { ди з питань професійної діяльності, редагувати, рецензувати, складати реферати } \\
\text { статей із предметної області }\end{array}$ & $\Phi K-5$ \\
\hline 6. & $\begin{array}{l}\text { Здатність володіти комп’ютерними методами збирання, зберігання, оброблення, } \\
\text { передавання інформації, що використовується у сфері професійної діяльності }\end{array}$ & $\Phi K-6$ \\
\hline 7. & Здатність використовувати сучасні мережеві інформаційні технології & $\Phi \mathrm{K}-7$ \\
\hline 8. & Здатність працювати в сучасних базах даних і базах знань & $\Phi K-8$ \\
\hline 9. & Здатність користуватися електронними таблицями, системою управління базами даних & $\Phi K-9$ \\
\hline 10. & $\begin{array}{l}\text { Здатність оброблення ділової інформації (економічної, статистичної тощо, поданої } \\
\text { у цифровій формі) }\end{array}$ & $\Phi K-10$ \\
\hline 11. & $\begin{array}{l}\text { Здатність підготовки документів на основі оброблених даних, що містять таблиці, } \\
\text { діаграми, графіки тощо }\end{array}$ & $\Phi \mathrm{K}-11$ \\
\hline 12. & $\begin{array}{l}\text { Здатність прийняття рішень на основі аналізу фактичних даних, складання про- } \\
\text { гнозів; пошук необхідної для прийняття рішень інформації у будь-яких доступних } \\
\text { джерелах за допомогою інформаційно-комунікаційних технологій }\end{array}$ & $\Phi \mathrm{\Phi}-12$ \\
\hline 13. & Здатність забезпечувати обмін даними на відстані & $\Phi K-13$ \\
\hline 14. & $\begin{array}{l}\text { Здатність організовувати та розробляти заходи щодо впровадження інформаційних } \\
\text { технологій у професійній діяльності }\end{array}$ & $\Phi K-14$ \\
\hline 15. & Здатність розуміти та/або організувати систему е-документообігу в організації & $\Phi \mathrm{K}-15$ \\
\hline 16. & $\begin{array}{l}\text { Здатність організовувати інформаційно-аналітичне забезпечення процесів діагнос- } \\
\text { тики та лікування із використанням сучасних інформаційних ресурсів і технологій }\end{array}$ & ФК-16 \\
\hline 17. & $\begin{array}{l}\text { Здатність розробляти та впроваджувати інноваційні проекти в різних лікувально- } \\
\text { діагностичних і управлінських процесах }\end{array}$ & $\Phi \mathrm{K}-17$ \\
\hline 18. & $\begin{array}{l}\text { Здатність виявляти наукову сутність питань/завдань у професійній сфері, знаходи- } \\
\text { ти адекватні шляхи щодо їх розв’язання }\end{array}$ & $\Phi K-18$ \\
\hline 19. & $\begin{array}{l}\text { Здатність вести дослідницьку діяльність, включаючи аналіз проблем, постановку } \\
\text { цілей і завдань, розроблення дизайну дослідження, а також оцінювання його якості }\end{array}$ & $\Phi K-19$ \\
\hline 20. & $\begin{array}{l}\text { Здатність здійснювати наукові дослідження в сфері медичної та біологічної інфор- } \\
\text { матики та кібернетики }\end{array}$ & $\Phi \mathrm{\Phi}-20$ \\
\hline 21. & $\begin{array}{l}\text { Здатність самостійно готувати нормативно-правові акти, аналітичні довідки, про- } \\
\text { позиції, доповіді }\end{array}$ & $\Phi \mathrm{K}-21$ \\
\hline 22. & $\begin{array}{l}\text { Здатність проводити експертне оцінювання нормативно-правових актів із викорис- } \\
\text { тання інформаційно-комунікаційних технологій в охороні здоров’я }\end{array}$ & ФК-22 \\
\hline 23. & $\begin{array}{l}\text { Здатність організовувати та розробляти заходи щодо впровадження інформаційних } \\
\text { технологій у процесах моніторингу стану здоров’я населення }\end{array}$ & ФК-23 \\
\hline
\end{tabular}




\begin{tabular}{|c|l|c|}
\hline № 3/п & \multicolumn{1}{|c|}{ Вид діяльності } & \multicolumn{1}{|c|}{ Кодування } \\
\hline 24. & $\begin{array}{l}\text { Здатність оцінювати валідність, компліментарність, конгруентність медичної/біо- } \\
\text { логічної інформації }\end{array}$ & ФК-24 \\
\hline 25. & $\begin{array}{l}\text { Здатність організовувати статистичне дослідження; оцінювати неоднорідність } \\
\text { статистичного матеріалу та її корекцію }\end{array}$ & $\Phi К-25$ \\
\hline 26. & Здатність застосовувати інформаційні стандарти & ФК-26 \\
\hline 27. & $\begin{array}{l}\text { Здатність використовувати методи прогнозування перебігу хвороби та оптимізації } \\
\text { вибору лікувальної тактики }\end{array}$ & ФК-27 \\
\hline 28. & $\begin{array}{l}\text { Здатність застосовувати принципи організації комп’ютерних навчальних та атеста- } \\
\text { ційних систем }\end{array}$ & ФК-28 \\
\hline 29. & $\begin{array}{l}\text { Здатність оцінювати валідність і надійність тестових питань у системах контролю } \\
\text { знань }\end{array}$ & ФК-29 \\
\hline 30. & $\begin{array}{l}\text { Здатність застосовувати стандарти отримання, зберігання, передавання та обро- } \\
\text { блення зображень у медицині }\end{array}$ & ФК-30 \\
\hline
\end{tabular}

\section{Планові результати навчання з дисципліни, співвіднесені з компетентностями}

У результаті освоєння дисципліни здобувач повинен:

\begin{tabular}{|c|c|}
\hline $\begin{array}{c}\text { Код } \\
\text { компетентності } \\
\end{array}$ & Перелік знань, умінь, навиків \\
\hline \multirow{3}{*}{$\begin{array}{l}\text { КПБ-1, КПО-2, } \\
\text { КПЕ-3, КПР-4, } \\
\text { КП-5, КСГ-1, } \\
\text { КСР-2, КСД-3, } \\
\text { КСК-4, АНІТ-1, } \\
\text { АШ3-2, АТ-3, } \\
\text { АНР-4, АНТ-5, } \\
\text { ВПВП-1, ВПНВ-2, } \\
\text { ВПГ-3, ВПС-4, } \\
\text { ВПОР-5, } \\
\text { ВПК-6, ЗК-1, 3К- } \\
\text { 2, 3К-3, } \\
\text { 3К-4, 3К-5, 3К-6, } \\
\text { 3К-7, 3К-8 }\end{array}$} & $\begin{array}{l}\text { Знати } \\
\text { принципи інформатизації та комп’ютеризації управління закладами охорони здоров’я } \\
\text { з використанням сучасних інформаційних технологій; алгоритми та структуру про- } \\
\text { грамних засобів підтримки прийняття рішень лікувально-діагностичного процесу }\end{array}$ \\
\hline & $\begin{array}{l}\text { Вміти } \\
\text { використовувати сучасні Інтернет-ресурси для пошуку професійної інформації при са- } \\
\text { мостійному навчанні та підвищенні кваліфікації з окремих розділів медичних/біологіч- } \\
\text { них знань (застосовувати алгоритм пошуку інформцції у спеціалізованих базах даних) }\end{array}$ \\
\hline & $\begin{array}{l}\text { Володіти } \\
\text { понятійним і функціональним апаратом медичної та біологічної інформатики і } \\
\text { кібернетики в обсязі, передбаченому змістом уніфікованої програми (використовува- } \\
\text { ти термінологію медичної та біологічної інформатики і кібернетики при здійсненні } \\
\text { процесів інформатизації діяльності), основними навиками використання медичних } \\
\text { інформаційних систем і Інтернет-ресурсів для реалізації професійних завдань }\end{array}$ \\
\hline \multirow[t]{3}{*}{$\begin{array}{l}\text { KO-1, KO-2, KO-3, } \\
\text { KO-4, KO-5, 3K-1, } \\
\text { 3K-2, 3K-3, 3K-4, } \\
\text { 3K-5, 3K-6, 3K-7, } \\
\text { 3K-8, } \\
\Phi K-1-30\end{array}$} & $\begin{array}{l}\text { Знати } \\
\text { теоретичні питання дисципліни в обсязі, передбаченому змістом уніфікованої програ- } \\
\text { ми; теоретичні основи інформатики та принципи побудови архітектури комп’ютерної } \\
\text { техніки, види, структуру, характеристики медичних інформаційних систем; основні } \\
\text { підходи до формалізації та структуризації різних типів медичних даних, що викорис- } \\
\text { товуються для формування рішень лікувально-діагностичного процесу }\end{array}$ \\
\hline & $\begin{array}{l}\text { Вміти } \\
\text { користуватися методами медичної та біологічної інформатики і кібернетики в обсязі, } \\
\text { передбаченому змістом уніфікованої програми (проектування баз даних), проводити } \\
\text { текстову та графічну обробку медичних даних із використанням стандартних засо- } \\
\text { бів операційних систем і загальноприйнятих офісних додатків, а також прикладних і } \\
\text { спеціальних програмних засобів }\end{array}$ \\
\hline & $\begin{array}{l}\text { Володіти } \\
\text { технологіями перетворення інформації з використанням текстових процесорів, елек- } \\
\text { тронних таблиць, реляційних систем управління базами даних (оброблення медико- } \\
\text { біологічної інформації із застосуванням пакетів прикладних програм) }\end{array}$ \\
\hline
\end{tabular}




\begin{tabular}{|c|c|}
\hline $\begin{array}{c}\text { Код } \\
\text { компетентності }\end{array}$ & \\
\hline \multirow{3}{*}{$\begin{array}{l}\text { КПБ-1, КПО-2, } \\
\text { КПЕ-3, КПР-4, } \\
\text { КП-5, КІО-1, } \\
\text { КІК-2, КІУ-3, } \\
\text { КІД-4, КІП-5, } \\
\text { КІС-6, ФК-1-30 }\end{array}$} & $\begin{array}{l}\text { Знати } \\
\text { способи збору, збереження, пошуку, оброблення, передавання інформації в медич- } \\
\text { них інформаційних системах; алгоритми та програмні засоби підтримки прийняття } \\
\text { рішень лікувально-діагностичного процесу }\end{array}$ \\
\hline & $\begin{array}{l}\text { Вміти } \\
\text { використовувати сучасні Інтернет-ресурси для пошуку професійної інформації при } \\
\text { самостійному навчанні та підвищенні кваліфікації за окремими розділами медичних } \\
\text { знань (використання сервісів Інтернет для професійного спілкування) }\end{array}$ \\
\hline & $\begin{array}{l}\text { Володіти } \\
\text { методами статистичного оброблення клінічних і експериментальних даних із засто- } \\
\text { суванням стандартних прикладних і спеціалізованих програмних засобів }\end{array}$ \\
\hline \multirow{3}{*}{$\begin{array}{l}\text { КО-1, } \\
\text { КО-2, КО-3, КО- } \\
\text { 4, КО-5, КПБ-1, } \\
\text { КПО-2, КПЕ-3, } \\
\text { КПР-4, } \\
\text { КП-5, } \\
\text { КІО-1, } \\
\text { КІК-2, } \\
\text { КІУ-3, } \\
\text { КІД-4, } \\
\text { КІП-5, } \\
\text { КІС-6, 3К-1, 3К-2, } \\
\text { 3К-3, } \\
\text { 3К-4, 3К-5, } \\
\text { 3К-6, 3К-7, } \\
\text { 3К-8, } \\
\text { ФК-1-30 }\end{array}$} & $\begin{array}{l}\text { Знати } \\
\text { види, структуру, характеристики медичних інформаційних систем способи збору, } \\
\text { збереження, пошуку, оброблення, передавання інформації в медичних інформацій- } \\
\text { них системах; основні підходи до формалізації і структуризації різних типів медич- } \\
\text { них даних, що використовуються при прийнятті рішень }\end{array}$ \\
\hline & $\begin{array}{l}\text { Вміти } \\
\text { використовувати статистичні та евристичні алгоритми, методи видобування знань із } \\
\text { «сирих» даних, застосовувати експертні системи для діагностики та управління; } \\
\text { використовувати сучасні Інтернет-ресурси для пошуку професійної інформації при } \\
\text { самостійному навчанні та підвищенні кваліфікації за різними розділами знань (по- } \\
\text { шук наукових статей в електронних журналах, інформаційних базах тощо); прийма- } \\
\text { ти рішення при неповній або нечіткій інформації }\end{array}$ \\
\hline & $\begin{array}{l}\text { Володіти } \\
\text { термінологією, пов'язаною з розробленням і впровадженням інформаційних і телекому- } \\
\text { нікаційних технологій для вирішення завдань охорони здоров’я (інтерпретація основних } \\
\text { термінів, пов'язаних із телекомунікація ми тощо); основними навиками застосування } \\
\text { медичних інформаційних систем та Інтернет-ресурсів для реалізації професійних завдань }\end{array}$ \\
\hline
\end{tabular}

\section{Оцінювання компетентностей}

Оцінювання компетентностей — це процес визначення ступеня відповідності здобувача запропонованому стандарту ефективності інформаційно-комунікаційної діяльності (професійні компетентності), соціальної активності (загальні компетентності), вдосконалення (ключові компетентності) тощо.

Використовуються психометричні методики, пов'язані з кількісним підходом до аналізу тестових даних. Можливе використання математичних моделей для аналізу відповідей на окремі завдання або пункти тестів, тести в цілому та набори тестів.

Для аналізу надійності тестування використовується критерій Кронбаха, що є найбільш поширеним показником надійності шкал.

Виділяють п’ять рівнів компетентності - базовий, проміжний, просунутий, спеціаліст та експертний. Вони відповідають аналогічному оцінюванню в системі ЕСТS.

Компетентності мають бути адаптивними та вдосконалюватись в залежності від характеру інформатизації охорони здоров'я, потреб практики та стану здоров'я населення.

Важливим елементом адаптивної системи оцінювання є оптимізація використання відповідних компетентностей, їх балансування та моніторинг протягом навчання.

Результат оцінювання компетентностей — можливість побудови індивідуальної траєкторії навчання та контролю знань здобувача, а також визначення прогнозних характеристик. 


\section{СПИСОК РЕКОМЕНДОВАНИХ ДЖЕРЕЛ}

\section{Обов'язкова література}

1. Концепція інформатизації охорони здоров’я України / Мінцер О. П., Вороненко Ю. В., Бабінцева Л. Ю. та ін. // Медична інформатика та інженерія. - 2012. - № 3. - С. 5-29.

2. Інформатизація охорони здоров'я: проблеми, розв'язані та нерозв'язані. Питання впорядкованості та сингулярності / Мінцер О. П. // Медична інформатика та інженерія. - 2013. - № 2. - С. 5-11.

3. Системно-біологічні та системно-медичні уявлення про функціонування організму. Частина 1. Упорядкування та структурування медичної інформації / О. П. Мінцер // Медична інформатика та інженерія. - 2018. - № 2. - С. 2-12.

4. Еволюція узагальнення, оброблення та передавання знань у медицині та біології / О. П. Мінцер, Д. В. Ватліцов // Медична інформатика та інженерія. - 2016. - № 1. - С. 12-14.

5. Інформаційні комунікатори в медицині / Мінцер О. П., Романов В. О., Зозуля І. С., Галелюка I. Б. // International Jounal «Information Models and Analyses». - 2014. - № 1. - C. 5-9.

6. Про загальне впорядкування медико-біологічних знань. Створення онтології / О. П. Мінцер, Л. Ю. Бабінцева // Медична інформатика та інженерія. - 2014. - № 2. - С. 5-8.

7. Концептуально-технологічні підходи в створенні єдиного медичного освітнього простору / О. П. Мінцер // Медична інформатика та інженерія. - 2015. - № 1. - С. 5-8.

8. Щодо межі доцільності використання поняття «тригерні взаємодії» у біології та медицині. Перше повідомлення — постановка проблеми / О. П. Мінцер, К. М. Ігрунова // Медична інформатика та інженерія. - 2014. № 4. - С. 14-22.

9. Щодо парадигми поєднання системно-біологічних і системно-медичних уявлень для формування нового погляду на діагностику та лікування ішемічної хвороби серця / О. П. Мінцер, Л. Ю. Бабінцева, Н. В. Харченко // Медична інформатика та інженерія. - 2018. - № 1. - С. 5-12.

10. Використання телемедицини у клінічній практиці: навч.-метод. посіб. Ч. 2 (для викладача) / Д. О. Добрянський, О. П. Мінцер, В. В. Краснов. - К.: Українсько-Швейцарська програма «Здоров’я матері та дитини», 2011. - 94 с.

11. Посібник з біостатистики. Аналіз результатів медичних досліджень у пакеті EZR (R-statistics): навч. посіб. / В. Г. Гур’янов, Ю. Є. Лях, О. В. Чалий, К. О. Чалий та ін. - К.: Вістка, 2018. - 208 с.

12. Інформатизація профілактичної медицини / O. П. Мінцер, Л.Ю.Бабінцева // В кн. Информатизация реабилитационного процесса : сб. науч. работ / под общ. ред. О. А. Панченко. - К.: КВИЦ, 2013. - 162 с.: ил.

13. Електронні навчальні посібники для відображення медичних процедурних знань: принципи, етапи створення, методологія / Вороненко Ю. В., Мінцер О. П., Краснов В. В. - К., 2009. - 160 с.

14. К обществу знаний: Всемирный доклад ЮНЕСКО. - Париж : ЮНЕСКО, 2005. - 211 с.

15. Оброблення клінічних і експериментальних даних у медилцині. Навч. посібник / О. П. Мінцер, Ю. В. Вороненко, В. В. Власов. - К.: Вища шк., 2003. - 350 с.

16. Доклад о состоянии здравоохранения в Европе 2015 г. Целевые ориентиры и более широкая перспектива новые рубежи в работе с фактическими данными. - Европейское региональное бюро ВОЗ, 2015. - Режим доступу: http://www.euro. who.int/ru/data-and-evidence/ european-health-report2015.

17. Комп’ютерні онтології та їх використання у навчальному процесі. Теорія і практика : монографія / С. О. Довгий, В. Ю. Велічко, Л. С. Глоба та ін. - К.: Інститут обдарованої дитини, 2013. - 310 с.

18. На шляху до європейського Грід / Петренко А. І., Свістунов С. Я., Корнелюк О. І. та ін. - К.: НТУУ «Київський політехнічний інститут», 2012. - 392 с.

19. Наномолекулярная медицина: современные биотехнололгии наномолекулярной диагностики, лучевые томографические методы визуализации, наномодифицированная клеточная и лекарственная терапия / В. Н. Залесский. - К., ВИПОЛ, 2009. - 320 с.

20. Биологическая деградация HOMO SAPIENS: пути протилводействия. Основы. Концепции. Методы / А. Апанасенко, В. Гаврилюк Saarbriicken : Palmarium Academic Publishing, 2014. - 96 с.

21. Онтологические методы и средства обработки предметных знаний: монография / А. В. Палагин, С. Л. Крывый, Н. Г. Петренко. - Луганск: ВНУ им. В. Даля, 2012. - 324 с.

22. Применение информационных технологий в современной реабилитологии / О. А. Панченко, О. П. Минцер. К.: КВИЦ, 2013. - 136 с.: ил.

23. Принятие решений. Метод анализ иерархий: пер. с англ. / Т. Саати. - М.: Радио и связь, 1993. - 278 с.

24. Универсум // Ж. Дидье. Философский словар: пер. с франц. - М.: Междунар. отношения, 2000. - 544 с.

25. Математическая логика / А. Н. Колмогоров, А. Г. Драгалин. - М.: УРСС, 2005. - 240 с.

26. Математическое моделирование живых систем : уч. пособие / О. Э. Соловьева, В. С. Мархасин, Л. Б. Кацнельсон и др. - Екатеринбург: Уральский университет, 2013. - 328 с. 
27. Частично упорядоченные алгебраические системы / Л. Фукс. - М.: Мир, 1965. - 342 с.

28. Математическая теория связи / К. Шеннон, У. Уивер; пер. с англ. под. ред. Р. Л. Добрушиной, О. Б. Лупановой // Работы по теории информации и кибернетике. - М.: Иностранная литература, 1963.

29. Применение методов распознавания при изучении здоровья населения : учеб. пособие / Е. Н. Шиган. - Центр. ин-т усовершенствования врачей. - М.: ЦОЛИУВ, 1977. - 76 с.

30. Теория и практика рационального выбора : монография / С. Д. Микони. - М.: Маршрут, 2014. - 463 с.

31. Многомерный статистический анализ с использованием ППП «STATISTICA»: уч.-метод, матер. / Буреева Н.

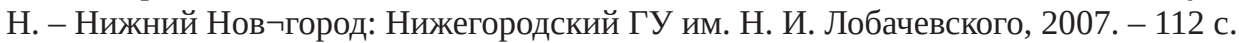

32. Створення модуля «Маршрутизацція пацієнта» в медичній інформаційній системі лікувального закладу : метод. рекомендації / Толстанов О. К., Майоров О. Ю., Мінцер О. П. та ін. - К.: КВІЦ, 2013. - 40 с.

33. Підготовка електронних видань, дидактичних демонстраційних матеріалів, електронних навчальних посібників та підручників в вищих медичних навчальних закладах: метод. рекомендації / Думанський Ю. В., Мінцер О. П., П’ятницький Ю. С. та ін. - К., 2015. - 29 с.

34. Біометрія: навч. посібник / О. П. Мінцер, Ю. С. Синєкоп, К. В. Ружицька. - К.: НВФ «Маrсh-А», 2008. - 253 с.

35. Інформаційні технології в хірургії / О. П. Мінцер, В. З.Молскаленко, С. В. Веселий. - К.: Вища школа, 2004. 423 с.: іл.

36. Використання флеш пам'яті WORM типу з розподіленими рівнями доступу для створення спеціалізованих реєстрів пацієнтів / Мінцер О. П., Бабінцева Л. Ю. / НМАПО імені П. Л. Шупика, МОЗ України // Реєстр галузевих нововведень. - К.: Укрмедпатентінформ. - 2013. - Вип. № 38-39, 4. - Реєстр. № 124/38/13. - С. 104-105.

37. Створення дуальної медичної інформаційної системи / Мінцер О. П., Бабінцева Л. Ю., Денисенко С. В. / НМАПО імені П. Л. Шупика, МОЗ України // Реєстр галузевих нововведень. - К.: Укрмедпатентінформ. - 2013. - Вип. № 38-39, 4. - Реєстр. № 126/38/13. - С. 105-106.

38. Інформаційні та мікроелектронні технології для застосування в мобільній медицині. Надії та обмеження / Мінцер О. П., Романов В. А., Галелюка І. В., Антонова А. В. // Медична інформатика та інженерія. - 2018. № 2. - C. 13-27.

39. Кардіологічні аспекти мережевої медицини / Мінцер О. П., Заліський В. М. // Медична інформатика та інженерія. - 2018. - № 3. - С. 17-27.

40. Кількісні характеристики комплементарності єдиної інформаційної системи охорони здоров’я та інформаційної системи управління обігом лікарських засобів / Л. Ю. Бабінцева // Медична інформатика та інженерія. 2014. - № 4. - С. 35-38.

41. Концептуальні засади застосування методології системної біомедицини для аналізу розвитку серцево-судинних захворювань / О. П. Мінцер, В. М. Заліський // Медична інформатика та інженерія. - 2018. - № 4. - С. 29-40.

42. Концептуальні узагальнення про роль просторових тригерних хвиль у системній біології та системній медицині / О. П. Мінцер, В. М. Заліський // Медична інформатика та інженерія. - 2018. - № 4. - С. 5-15.

43. Концептуальні узагальнення щодо структурної організації комп’ютерних мереж вищих медичних навчальних закладів / О. П. Мінцер, О. А. Рижов, В. П. Марценюк, В. В. Краснов // Медична інформатика та інженерія. 2013. - № 4. - С. 7-15.

44. Математическое моделирование при решении задач классификации в биомедицине / Лях Ю. Е., Гурьянов В. Г. // Українский журнал телемедицини та медичної телематики. - 2012. - № 2 (10). - С. 69-76.

45. Методи системної біології в оцінюванні глобальних перебудов клітинного метаболізму при хронічних захворюваннях обміну речовин / Мінцер О. П., Заліський В. М. // Медична інформатика та інженерія. - 2018. № 3. - С. 36-43.

46. Методи системної біології в оцінюванні глобальних перебудов клітинного метаболізму при хронічних захворюваннях обміну речовин / О. П. Мінцер, В. М. Заліський // Медична інформатика та інженерія - 2018. № 3. - C. 36-43.

47. Мобильные приложения для здоровья / В. Г. Абдуллаев, Т. К. Аскеров, И. В. Чуба // Радиоэлектроника и информатика. - 2014. - Т. 1, № 64.

48. Можливості застосування технологій дистанційного навчання в безперервному професійного розвитку провізорів / Л. Ю. Бабінцева // Медична інформатика та інженерія. - 2015. - № 1. - С. 18-22.

49. Мережева основа функціонування біологічних осциляторів - тригерів коливальних ланцюгів у клітинах і безклітинних системах. Аналітичний огляд / О. П. Мінцер, В. М. Заліський, Л. Ю. Бабінцева // Медична інформатика та інженерія. - 2019. - № 1. - С. 59-72.

50. Обрії розвитку адаптивного навчання / О. П. Мінцер // Медична інформатика та інженерія. - 2017. - № 1. - С. 5-11.

51. Онтології в фармації / Л. Ю. Бабінцева // Медична інформатика та інженерія. - 2014. - № 3. - С. 9-12.

52. Онтологічна модель процесів програмованої клітинної загибелі / О. П. Мінцер, Д. В. Ватліцов // Медична інформатика та інженерія. - 2015. - № 2. - С. 14-26. 
53. Особенности разработки концептуальной математической модели для процесса раннего диагностирования наследственных орфанных заболеваний / Бабинцева Л. Ю., Стецюк В. З., Малей А. В. // Медична інформатика та інженерія. - 2018. - № 2. - С. 44-51.

54. Персонализированная медицина: современное состояние и перспективы / И. И. Дедов, А. Н. Тюльпаков, В. П. Чехонин и др. // Вестник РАМН. - 2012. - № 12. - С. 4-10.

55. Про програмне середовище проектування інтелектуальних медичних баз даних / Марценюк В. П., Кравець Н. О. // Клін. інформат. і телемед. - 2004. - Т. 1, № 1. - С. 47-53.

56. Проблеми зберігання медичної та біологічної інформації / Петров В. В., Мінцер О. П., Крючин А. А., Крючина Є. А. // Медична інформатика та інженерія. - 2017. - № 3. - С. 14-23.

57. Розробка і впровадження системи електронного навчання в Тернопільському державному медичному університеті імені І. Я. Горбачевського / Марценюк В. П. // Мед. освіта. - 2008. - № 2. - С. 74-75.

58. Телемедицинские технологии и научные исследования / Вишневский В. В. // Укр. журн. телемедицини та медичної телематики. - 2006. - Т. 4, № 1. - С. 57-61.

59. ТОДОС - ІТ-платформа формування трансдисциплінарних інформаційних середовищ / В. Ю. Величко, М. А. Попова, В. В. Приходнюк, О. Є. Стрижак // Системи озброєння і військова техніка. - 2017. - № 1. - С. 10-19.

60. Трансформація післядипломної медичної освіти в умовах масового впровадження інформаційних технологій / Вороненко Ю. В., Мінцер О. П. // Медична освіта. - 2019. - № 3(84) Додаток. - С. 38-40.

61. Трансформування знань з атерогенезу: використання нано-асоційованих біотехнологій і мережевого аналізу / О. П. Мінцер, В. М. Заліський // Медична інформатика та інженерія. - 2019. - № 1. - С. 4-24.

62. Virtual laboratory MoldynGrid as a part of scientific infrastructure for biomolecular simulations / Сальніков А. О, Слюсар I. А., Корнелюк О. І. та ін. // Міжнародний журнал Комп’ютинг. - 2010. - Т. 9, № 4. - С. $294-300$.

63. Handbook of Coherent-Domain Optical Methods / Yu. A. Ushenko, T. M. Boychuk, V. T. Bachynsky, O. P. Mincer. Diagnostics of Structure and Physiological State of Birefringent Biological Tissues: Statistical, Correlation and Topological Approaches, 2013. - P. 107-148.

64. Methodical issues of assuring doctors' portfolio information reliability during continuous medical education / Mintser O. P., Babintseva L. Yu., Dyadyk O. A., Sukhanova O. A. // Regional innovations (France). Medical Science. - 2018. - № 3. - P. 32-36.

65. Objective assessment in continual medical education (CME) medical objective assessment in system control / Ivanov D. D., Voronenko Yu. V., Mintser O. P., Babintseva L. Yu. // Pisco Med Publishing Pte. Ltd. Singapore. - 2018. - Режим доступу: http://ojs.piscomed.com/index.php /JIM/article/view.

66. Promissory Concept of medical education / O. Mintser, Yu. Voronenko, D. Ivanov // Journal of European CME. - 2015. - V. 4. - 25135. - Режим доступу: http://dx.doi.org/10.3402/ jecme.v4.25135.

67. On Data Mining Technique for Differential Diagnostics Based on Data of Arterial Oscillography / Mintser O., Martsenyuk V., Vakulenko D. // Mechanisms and Machine Science. - Vol. 70, 2020. - P. 253-262.

68. Medical physics: Molecular aspects / Chekhun, V. F., Zabashta, Y. F., Chalyi K. O. et al. // Укр. фіз. журн. - 2015. T. 60, № 9. - C. 892-904.

69. A systems biology and proteomics-based approach identifies SRC and VEGFA as biomarkers in risk factors mediated coronary heart disease / A. Vincent, P. Nayar, R. Murugesan et al. // Mol. Biosyst. - 2016. - Vol. 12, No. 8. - P. 25942604.

70. Animal and in silico models for the study of sarcomeric cardiomyopathies / D. Duncker, J. Bakkers, B. Brundel et al. // Cardiovasc. Res. - 2015. - Vol. 105, No. 4. - P. 439-448.

71. Systems medicine: the future of medical genomics and healthcare / C. Auffray, Z. Chen, L. Hood // Genome Med. 2009. - Vol. 1, No. 1. - P. 2.

72. Clinical application of pharmacogenetics / B. Spear, M. Heath-Chiozzi, J. Huff // Trends Mol. Med. - 2001. - Vol. 7, № 5. - P. 201-204.

73. Deploying whole genome sequencing in clinical practice and public health: Meeting the challenge one bin at a time / J. S. Berg, M. L. Khoury, J. P. Evans // Genetics in Medicine. - 2011. - Vol. 13, № 6. - P. 499-504.

74. From molecular diagnostics to personalized medicine / K. K. Jain // Exp. Rev. Mol. Diagn. - 2002. - Vol. 2, № 4. P. 299-301.

75. Genomics contest underscores challenges of personalized medicine / M. Scudellari // Nat. Med. - 2012. - Vol. 18, № 3. - P. 326.

76. Molecular diagnostics for personal medicine using a nanopore / U. M. Mirsaidov, D. Wang, W. Timp, G. Timp // Wiley Interdiscip. Rev. Nanomed. Nanobiotechnol. - 2010. - Vol. 2, No, 4. - P. 367-381.

77. Nanobiotechnology and personalized medicine / K. K. Jain // Prog. Mol. Biol. Transl. Sci. - 2011. - Vol. 104. P. 325-354.

78. Personalize medicine: temper expectations / D. W. Nebert, G. Zhang // Science. - 2012. - Vol. 337, № 6097. - P. 910. 
79. Personalized medicine trends in molecular diagnostics: exponential growth expected in the next ten years / J. Hoggatt // Mol. Diagn. Ther. - 2011. - Vol. 15, № 1. - P. 53-55.

80. Personalized medicine: progress and promise / I. S. Chan, G. S. Ginsburg / Annu. Rev. Genomics Hum. Genet. - 2011. - Vol. 12. - P. 217-244.

81. Personalized vascular medicine: individualizing drug therapy / E. M. DeGoma, G. Rivera, S. M. Lilly // Vascular Med. - 2011. - Vol. 16, № 5. - P. 391-04.

82. Stability, bifurcation and transition to chaos in a model of immunosensor based on lattice differential equations with delay / V. Martsenyuk, A. Kłos-Witkowska, A. Sverstiuk // Electronic Journal of Qualitative Theory of Differential Equations. - 2018. - No. 27. - P. 1-31.

83. The economics of personalized medicine: a model ol incentives for value creation and capture / L. P. Garrison Jr., M. J. Austin // Drug Information Journal. - 2007. - Vol. 41. - P. 501-509.

84. The faces of personalized medicine: a framework for understanding its meaning and scope / W. K. Redekop, D. Mladsi // Value Health. - 2013. - Vol. 16, Suppl. 6. - P. 4-9.

85. The path to personalized medicine / M. A. Hamburg, F. S. Collins // N. Engl. J. Med. - 2010. - Vol. 363, № 4. P. 301-304.

\section{Нормативні документи}

1. Закон України «Про вищу освіту» із змінами від 01.07.2014 № 1556-VII. - Режим доступу: https://zakon.rada. gov.ua/laws/show/1556-18.

2. Закон України «Про освіту» із змінами від 05.09.2017 № 2145-VIII. - Режим доступу: https://zakon.rada.gov.ua/ laws/show/2145-19.

3. Постанова Кабінету Міністрів України «Про затвердження переліку галузей знань і спеціальностей, за якими здійснюється підготовка здобувачів вищої освіти» із змінами від 29.04.2015 № 266. - Режим доступу: https://zakon.rada. gov.ua/laws/show/266-2015-\%D0\%BF.

4. Постанова Кабінету Міністрів України «Про затвердження національної рамки кваліфікацій» із змінами від 23.11.2011 № 1341. - Режим доступу: https://zakon.rada.gov.ua/laws/show/1341-2011-\%D0\%BF.

5. Національний класифікатор України: Класифікація видів економічної діяльності. ДК 009:2010 із змінами. Чинний від 01.01.2012. Режим доступу: https://zakon.rada.gov.ua/rada/show/vb457609-10.

6. Закон України «Про Національну програму інформатизації» із змінами від 04.02.1998 № 74/98-ВР. - Режим доступу: https://zakon.rada.gov.ua/laws/show/74/98-\%D0\%B2\%D1\%80.

7. Закон України «Про інформацію» від 02.10.1992 № 2657-XII. - Режим доступу: https://zakon.rada.gov.ua/laws/ show/2657-12.

8. Закон України «Про захист інформації в автоматизованих системах» від 31.05.2005 № 2594-IV. - Режим доступу: https://zakon.rada.gov.ua/laws/show/2594-15.

9. Закон України «Про електронні документи та електронний документообіг» від 22.05.2003 № 851-IV. - Режим доступу: https://zakon.rada.gov.ua/laws/show/851-15.

10. Закон України «Про електронні довірчі послуги» від 05.10.2017 № 2155-VIII. - Режим доступу: https://zakon. rada.gov.ua/laws/show/2155-19.

11. Закон України «Про захист інформації в інформаційно-телекомунікаційних системах» від 05.07.1994 № 80/94BP. - Режим доступу: https://zakon.rada.gov.ua/laws/show/80/94-\%D0\%B2\%D1\%80.

12. Закон України «Про захист персональних даних» від 01.06.2010 № 2297- VI. - Режим доступу: https://zakon. rada.gov.ua/laws/show/2297-17.

13. Закон України «Основи законодавства України про охорону здоров’я» із змінами від 19.11.1992 № 2801-XII. Режим доступу: https://zakon.rada.gov.ua/laws/show/2801-12.

14. Закон України «Про національну безпеку України» від 21.06.2018 № 2469-VIII. - Режим доступу: https://zakon. rada.gov.ua/laws/show/2469-19.

15. Закон України «Про стандартизацію» від 05.06.2014 № 1315-VII із змінами. - Режим доступу: https://zakon. rada.gov.ua/laws/show/1315-18.

16. Конвенція про захист прав та гідності людини у зв’язку з використанням досягнень біології та медицини. ETS-164, Ов’єдо, 04.04.1997. - Режим доступу: https://www.coe.int/ru/web/conventions/full-list/-/conventions/ treaty/164.

17. Конвенція про захист особистості відносно автоматизованого оброблення даних особистого характеру (Страсбург, 28.01.1981, European Treaty Series/108). - Режим доступу: https://zakon.rada.gov.ua/laws/show/994_326. (в Україні Конвенцію ратифіковано із заявами згідно із Законом № 2438-VI від 06.07.2010).

18. Наказ МО3 «Про впровадження телемедицини в закладах охорони здоров’я» від 26.03.2010 № 261. - Режим доступу: https://zakon.rada.gov.ua/rada/show/v0261282-10. 
19. Наказ МОЗ «Про затвердження нормативних доку лментів щодо застосування телемедицини у сфері охорони здоров’я» від 19.10.2015 № 681. - Режим доступу: https://zakon.rada.gov.ua/laws/show/z1400-15.

20. Nuffield Council on Bioethics (2010). Medical profiling and online medicine: the ethics of 'personalised healthcare' in a consumer age. - Режим доступу: http://nuffieldbioethics.org/wp-content/uploads/2014/07/Medical-profiling-andonline-medicine-the-ethics-of-personalised-healthcare-in-a-consumer-age-Web-version-reduced.pdf.

21. Health informatics - Electronic health record - Definition, scope and context : ISO/TR 20514:2005. Чинний із 22.01.2005. - ISO, 2005. - 27 р. - (Міжнародний стандарт). - Режим доступу: https://www.iso.org/standard/39525.html.

22. Здоровье - 21: основы политики достижения здоровья для всех в Европейском регионе ВОЗ // Европейская серия по достижения здоровья для всех, № 6. - Копенгаген: ЕРБ ВОЗ, 1999. - 310 с.

23. ДСТУ 3396.2-97 Захист інформації. Технічний захист інформації. Терміни та визначення.

24. Наказ ДСТСЗІ СБ України № 50 від 10.05.06 «Правила посиленої сертифікації».

25. ДСТУ 33960-96 Захист інформації. Технічний захист інформації. Основні положення.

26. НД ТЗІ 1.1-003-99 Термінологія в галузі захисту інформації в комп’ютерних системах від несанкціонованого доступу.

27. НД ТЗІ 2.5-004-99 Критерії оцінки захищеності інформації в комп’ютерних системах від несанкціонованого доступу.

28. НД ТЗІ 3.6-001-2000 Технічний захист інформації. Комп’ютерні системи. Порядок створення, впровадження, супроводження та модернізації засобів технічного захисту інформації від несанкціонованого доступу.

\section{Рекомендована література}

1. Англо-український словник з інформатики та обчислюваль ᄀної техніки / Коссак О. М. - Львів: БаК, 1995. 304 с.

2. Базы знаний интеллектуальных систем / Т. А. Гаврилова, В. Ф. Хорошевский. - С.-Пб.: Питер, 2001. - 384 с.

3. Биоэкомедицина. Единое информационное пространство / В. И. Гриценко, О. П. Минцер, М. И. Вовк, А. Б. Котова. - К.: Наукова думка, 2001. - 318 с.

4. Валеология: становление и пути развития. (Научная серия «Проблемы причинности в валеологии») / Г. Л. Апанасенко, О. П. Минцер, В. П. Гоч и др. - Севастополь: Лаукар, 1999. - 80 с.

5. Введение в технологию Грид / Кирьянов А. К., Рябов Ю. Ф. - М.: Гатчина, 2006. - 39 с.

6. Використання телемедицини у клінічній практиці: навч.-метод. посібник / Д. О. Добрянський, О. П. Мінцер, В. В. Краснов. - К.: Українсько-Швейцарська програма «Здоров’я матері та дитини», 2011. - Ч. 1 (для слухача). -86 с.

7. Зелена книга Національного плану дій з безпеки пацієнтів та матеріали Першого налціонального конгресу з безпеки пацієнтів / П. Мієржевський, В. Г. Сердюк, О. П. Мінцер, Л. Ю. Бабінцева. - К., 2012.

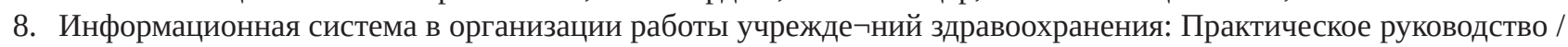
И. П. Дуданов, Ф. А. Романов, А. В. Гусев. - Петрозаводск: ПетрГУ, 2005. - 238 с.

9. Информационные системы в здравоохранении / Гусев А. В., Романов Ф. А., Дуданов И. П., Воронин А. В. Петрозаводск: ПетрГУ, 2002. - 120 с.

10. Информационные технологии оценки здоровья населения (на примере г. Славутича) / О. П. Мінцер, В. П. Зотов, А. Б. Котова, В. Н. Шиленко. - К.: МЕДЭКОЛ, 1998. - 96 с.

11. Інтернет для лікарів: навч.-метод. посібник для лікарів-інтернів і лікарів-слухачів курсів підвищення кваліфікації закладів (факультетів) післядипломної освіти / Мінцер О. П., Бабінцева Л. Ю., Мохначов С. І. та ін. - Кіровоград: Полімед-Сервіс, 2003. - 76 с.

12. Качественная клиническая практика с основами доказательной медицины: уч. пособие для системы послевузовского и дополнительного профес-сионального образования врачей / под общ. ред. акад. РАМН, проф. Р. Г. Оганова. - М.: Силицея-Полиграф, 2011. - 136 с.

13. Клеточные автоматы: уч.-метод. пособие / Астафьев Г. Б., Короновский А. А., Храмов А. Е. - Саратов: Колледж, 2003. - 24 с.

14. Людина в інформаційному суспільстві: проблеми адаптації та управлінського впливу / Н. В. Коноваленко. Режим доступу: http://www.N<jbuv.gov.ua/portal/ Soc_Gum/Afkps/2009_23.pdf.

15. Математические методы принятия решений: учеб. пособие / Бодров В. И., Лазарева Т. Я., Мартемьянов Ю. Ф. - Тамбов: Тамб. ГТУ, 2004. - 124 с.

16. Медицинская информатика: практикум / Гельман В. Я. - С.- Пб: Питер, 2001. - 480 с.

17. Медицинская статистика / Лукьянова Е. А. - М.: РУДН, 2002. - 255 с.

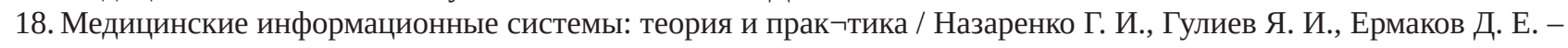
М.: ФИЗМАТЛИТ, 2005. - 320 с.

19. Основи доказової медицини / Скакун М. П. - Тернопіль: Укрмедкнига, 2005. -188 с. 
20. Основные принципы применения статистических методов в клинических испытаниях / Лапач С. Н., Чубенко А. В., Бабич П. Н. - К.: Морион, 2002.

21. Основы доказательной медицины / Гринхальх Т. - М.: ГЭОТАР-Медиа, 2001. - 240 с.

22. Очерки о совместной работе математиков и врачей (2-е, доп. изд.) / Гельфанд И. М., Розенфельд Б. И., Шифрин M. A. - M.: УРCС, 2004. - 234 с.

23. Практичне використання пакета STATISTICA для аналізу медико-біологічних даних: навч. посібник / Гойко О. B. - K., 2004. - 76 с.

24. Програмування: навчальний посібник / В. В. Зубенко, Л. Л. Омельчук. - К.: Київський університет, 2011. - 623 с.

25. Современная клиническая практика в свете доказательной медицины / Мінцер О. П. // Ортопедия, травматология и протезирование. - 2005. - № 2. - С. 95-99.

26. Статистические методы в медико-биологических исследованиях с использованием Excel / Лапач С. Н., Чубенко А. В., Бабич П. Н. - К.: Морион, 2000. - 320 с.

27. Телемедицина / Блажис А. К., Дюк В. А. - С.-Пб.: СпецЛит, 2001. - 143 с.

28. Телемедицина в системе практического здравоохранелния / Кобринский Б. А. - М.: МЦФЭР, 2002. - 176 с.

29. Теория вероятностей и математическая статистика / Гмурман В. - К.: Высшая школа (7-е изд.), 2001. - 346 с.

30. Теория вероятностей и математическая статистика / Кремер Н. - Юнити, 2001. - 543 с.

31. Теория вероятностей и прикладная статистика / Айвазян С. А, Мхитарян В. С. - Т. 1. - Юнити, 2001. - 656 с.

32. Технології дистанційного навчання у практичній медицині / О. П. Мінцер, Ю. В. Вороненко // Журнал сучасного лікаря. Мистецтво лікування. - 2003. - № 7 (023). - С. 8-11.

33. Удосконалення самостійної роботи студентів - необхідна умова реалізації ідей Болонського процесу / Л. Є. Ковальчук, В. І. Шутак, П. М. Телюк // Галицький лікарський вісник. - 2008. - Т. 15, № 1. - С. 79-80.

\section{Інші рекомендовані джерела}

1. Методичні рекомендації щодо розроблення стандарту вищої освіти, затверджені Наказом Міністерства освіти і науки України № 1648 від 21.12.2017. - Режим доступу: https://mon.gov.ua/storage/app/media/vishcha-osvita/ rekomendatsii1648.pdf.

2. Розроблення освітніх програм. Методичні рекомендації. - Режим доступу: http://ihed.org.ua/images/doc/04_2016_ rozroblennya_osv_program_2014_tempusoffice.pdf.

3. Національний освітній глосарій: вища освіта. - Режим доступу: https://ihed.org.ua/images/biblioteka/glossariy_ Visha_osvita_2014_tempusoffice.pdf.

4. Розвиток системи забезпечення якості вищої освіти в Україні: інформаційноаналітичний огляд. - Режим доступу: https://erasmusplus.org.ua/... informatsiia/.../3- materialy-natsionalnoi-komandy-ekspertiv.

5. Європейська кредитна трансферна накопичувальна система: довідник користувача. - Режим доступу: http:// www.kname.edu.ua/images/ Files/ECTS/2016_ECTS_Users_Guide-2015_Ukrainian_translation.pdf.

6. Стандарти і рекомендації щодо забезпечення якості в Європейському просторі вищої освіти. - К. : Ленвіт, 2006. - 35 с.

7. Глосарій Програми розвитку ООН. - Режим доступу: http://www.unpan.org/Directories/ UNPublicAdministrationGlossary.

8. Аналітичний ресурс місцевого і регіонального розвитку. - Режим доступу: www.municipal.gov.ua/1426.

9. Верховна Рада України. - Режим доступу: www.rada.gov.ua.

10. Громадянське суспільство і влада. - Режим доступу: www.civic.kmu.gov.ua.

11. Інститут Масової Інформації. - Режим доступу:www.imi.org.ua.

12. Кабінет Міністрів України - Режим доступу:www.kmu.gov.ua.

13. Мережа аналітичних центрів України. - Режим доступу:www.intellect.org.ua.

14. Портал «Громадський простір». - Режим доступу:www.civicua.org.

15. Сайт Інституту Громадянського суспільства. - Режим доступу:www.csi.org.ua.

16. Сайт проекту «LARGIS» Посилення Інституційної спроможності місцевих і регіональних органів влади. Режим доступу: www.largis.org.ua.

17. TUNING (для ознайомлення зі спеціальними (фаховими) компетентностями та прикладами стандартів. - Режим доступу: http://www.unideusto.org/tuningeu.

18. MSIS 2006. Model Curriculum and Guidelines for Graduate Degree Programs in Information Systems / J. T. Gorgone, P. Gray, E. A. Stohr et al. // Communications of AIS, Vol. 17, Article 1. - Режим доступу: http://www.acm.org/ education/curric_vols/ MSIS\%202006. pdf.

19. CWA 14925:2004 Generic ICT Skills Profiles for the ICT supply industry - a review by CEN/ISSS ICT-Skills Workshop of the Career Space work.

20. CWA 15005:2004 ICT Curriculum Development Guidelines for the ICT supply industry - a review by CEN/ISSS ICT skills Workshop of the Career Space work. 
21. CWA 15893-1:2008 European e-Competence Framework - Part 1: The Framework (replaced by CWA 16234:2010 Part 1); Part 2: User Guidelines (replaced by CWA 16234:2010 Part 2).

22. CWA 16234-1:2010 European e-Competence Framework 2.0- Part 1: A Common European Framework for ICT Professionals in All Industry Sectors; Part 2: User guidelines for the application of the European e-Competence Framework 2.0; - CWA 16213 :2010 End User e-Skills Framework Requirements.

23. CWA 16458:2012 European ICT Professional Profiles; - CWA 16624-1:2013 e-Competence Framework for ICT Users- Part 1: Framework Content; Part 2: User Guidelines; Part 3: Development Guidelines.

24. CWA 16052-2:2013 ICT Certification in Action (revised CWA 16052 :2009).

25. The UK Quality Code for Higher Education, Subject Benchmark Statements. - Режим доступу: http://dera.ioe.ac.uk/23774/.

26. Information Technology Curricula 2017. Curriculum Guidelines for Baccalaureate Degree Programs in Information Technology. - Режим доступу: https:/www.acm.org/binaries/content/assets/education/curricularecommendations/ it2017.pdf.

27. Information Systems 2010. Curriculum Guidelines for Undergraduate Degree Programs in Information Systems. - Peжим доступу: https://www.acm.org/ binaries/content/assets/education/curricula-recommendations/is-2010-acm-final.pdf.

28. Моделирование сложных систем / Амосов Н. М. - К.: Наукова думка, 1968.

29. Биологическая и медицинская кибернетика. Справочник / Минцер О. П., Молотков В. Н., Угаров Б. Н. и др. К.: Наукова Думка, 1985.

30. Медико-биологическая статистика / Гланц С. - М.: Практика, 1999. - 459 с.

31. Системы обработки и хранения информации / Трофимова И. П. - М.: Высшая школа, 2003.

32. Человеко-машинные системы принятия решений с элементами искусственного интеллекта / Гурасимов Б. М., Тарасов В. А., Токарев И. В. - К.: Наукова думка, 2003. -184 с.

33. Синергетика / Хакен Г. - М.: Мир, 1980.

34. Синергетика и прогнозы будущего / Капица С. П., Курдюмов С. П., Малинецкий Г. Г. - М.: Наука, 1997.

35. Вычислительные методы теория принятия решений / Юдин Д. Б. - М.: Наука. Гл. ред. физ.-мат. лит., 2002.

36. Медицинская информатика: практикум / Гельман В. Я. - С.-Пб.: Питер, 2001. - 480 с.

37. Кибернетика в сердечной хирургии / Минцер О. П., Кнышов Г. В., Цыганий А. А. - К.: Вища школа, 1984. - 140 с.

38. Системы отображения в медицине / Абакумов В. Г., Рыбин А. И., Сватош И., Синекоп Ю. С. - К.: Юніверс, 2001. - 336 с.

39. Руководство по экспертным системам / Уоттерман Д. - М.: Мир, 1989.

40. Компьютер для врача. Самоучитель / Герасевич В.А. - С.-Пб.: БХВ-Петербург, 2004. - 512 с.

41. Наглядная статистика в медицине / Петри А., Сэбин К. - М.: Гэотар-Мед, 2003.

42. Медична і біологічна фізика: Підручник / Чалий О. В., Агапов Б. Т., Цехмістер Я. В. та ін. - К.: Книга плюс, 2005. - 760 с.

43. Нові інформаційні технології: Транспортні мережі телекомунікацій / Стеклов В. К., Беркман Л. Н. - К.: Техніка, 2004. -488 c.

44. Statistica: искусство анализа данных на компьютере / Боровиков В.П. - С.-Пб.: Питер, 2001.

45. Компьютерная графика / Петров М. Н., Молочков В. П. - С.-Пб.: Питер, 2002.

46. Защита от компьютерного терроризма / Соколов А. В., Степанюк О. М. - С.-Пб.: БХВ - Петербург, Арлит, 2002.

47. Data Mining: уч. Курс / Дюк В., Самойленко А. - С.-Пб.: Питер, 2001. - 368 с.

48. Информационные технологии в медико-биологических исследованиях / Дюк В., Эмануэль В. - С.-Пб.: Питер, 2003. - 528 с.

49. Автоматизированные информационные системы, базы и банки данных. Вводный курс: уч. Пособие / Гайдамакин Н. А. - М.: Гелиос АРВ, 2002.

50. Математико-статистическая обработка данных медицинских исследований / Юнкеров В. И., Григорьев С. Г. С.-Пб.: ВМедА, 2002. - 266 с.

51. Электрофизиологическая и фотометрическая медицинская техника / Попечителев Е. П., Кореневский Н. А. М.: Высшая школа, 2002.

52. Клиническая эпидемиология. Основы доказательной медицины / Флетчер Р., Флетчер С., Вагнер Э. - М.: МедиаСфера, 1998. - 352 с.

53. Охорона праці користувачів комп’ютерних відеодисплейних терміналів / Навакатікян О. О., Кальниш В. В., Стрюков С. М. - К.: Основа, 1997. - 400 с.

\section{Електронні ресурси}

1. New England Medical Journal. - Режим доступу: http://www.nejm.org.

2. Ланцет. - Режим доступу: http://www.thelancet.com.

3. Британський медичний журнал. - Режим доступу: http://www.bmj.com/bmj. 
4. Журнал Американської медичної асоціації. - Режим доступу: www-amaassn.org/journals/standing/jama/jamahome.html.

5. Режим доступу: http://www.webmedlit.com.

6. Всесвітня Організація Охорони Здоров’я. - Режим доступу: http: //www.who.ch.

7. Інформаційне агентство CNN (новини охорони здоров’я). - Режим доступу: www.cnn.com/health.

8. Американська медична асоціація. - Режим доступу: www.ama-assn.org; FDA. - Режим доступу: www.fda.gov.

9. Сервер з проблем ефективності і економіки охорони здоров’я США. - Режим доступу: www.york.ac.uk.

10. Канадська медична асоціація (СМА). - Режим доступу: www.ста.са; Ендокринологічне суспільство США. Режим доступу: www.endo-society.org.

11. Суспільство «Інтернет в медицині». - Режим доступу: www.pavilion.co.uk/mednet/.

12. Телемедичний словник Нью-йоркського університету. - Режим доступу: http://kellogg.cs.hscsyr.edu/ wwwserv/ telemedicine/glossary.html.

13. Національний інститут здоров’я США. - Режим доступу: www.nih.gov.

\section{Предметно-тематичні каталоги}

1. Національна медична бібліотека США. - Режим доступу: http:/www.nih.gov/.

2. Центр профілактичної медицини (США). - Режим доступу: www.cdc.gov.

3. Консиліум-Медікум. - Режим доступу: www.consilium-medicum.com.

4. Інформація по онкології. - Режим доступу: http://www.cancer.med.upenn.edu.

5. Інформація по психіатрії. - Режим доступу: http://www.mentalhealth.com.

6. Підписка на журнал по неврології. - Режим доступу: http://www-mitpress.mit.edu.

7. Найостанніші новини з медицини. - Режим доступу: http://www.dash.com.

8. Medline, Embase, Biosys, DrugNL тощо. - Режим доступу: http://www.fizkarlsruhe.de.

9. Телемедицина (англомовні сервери). - Режим доступу: www.telemedmag.com, www.telemedtoday.com.

10. Международная академия открытого образования. - Режим доступу: http://www.maoo.ru. 


\section{РЕСУРСИ САМОНАВЧАННЯ}

3 дисципліни «Медична та біологічна інформатика і кібернетика»

для здобувачів вищої освіти ступеня доктора філософії

(очна (денна, вечірня), заочна форми навчання)

за спеціальностями: 224 - Технології медичної діагностики та лікування, 091 - Біологія

Тривалість навчання: 2,0 міс. (12 кредитів, 360 год.)

Забезпечення отримання різних поглядів на суть процесів — основа становлення особистості. Сучасні технології забезпечують можливості отримання майже всієї світової інформації. Загальновизнано, що людство знаходиться на порозі цифрової освітньої революції, коли традиційні методи отримання знань замінюються можливостями розроблення особистого навчального плану. Інтернет став найпотужнішим інструментом для навчання, що коли-небудь був винайденим. Найближчим часом реаліями стануть нові технології, такі як доповнена реальність, віртуальна реальність, штучний інтелект, що дозволять вивчати та досліджувати будь-який факт, який зацікавить особистість.

Можливості для самоосвіти та навчання протягом усього життя безмежні. Вони включають використання онлайн курсів, створення свого власного веб-сайту, дослідження світу зі своїм телефоном (або іншим мобільним пристроєм), співпрацю з іншими здобувачами вищої освіти, дослідниками, вченими.

Тому для забезпечення самостійної роботи здобувача викладач повинен визначити та оцінити: вихідний рівень самоосвітньої компетентності здобувача; наявність усвідомленої потреби в самостійної освіти та її мотивів; ставлення здобувача до джерел і засобів самоосвіти в професійній сфері; рівень сформованості у здобувача вмінь і навиків проведення самостійної освітньої роботи.

Здобувач має визначити цілі самостійної роботи — найближчої та віддаленої; здійснення загального орієнтування в навчальному матеріалі (знайомство з переліком питань по темі, якщо такі є; складання уявлення про обсяг, характер і ступінь новизни інформації (навчальної, наукової тощо).

Інформаційні інструменти, що рекомендуються здобувачеві для самонавчання (табл. 2):

1. Evernote - аутсорсинг ідей і заміток у цифровій пам'яті за допомогою Evernote.

2. Feedly — підписка на веб-сайти, що часто використовуються при застосуванні своїх RSS-каналів.

3. Flipboard - спосіб перегляду останніх новин.

4. Pocket - технології збереження статей із електронних ресурсів у цифровій кишені.

5. Google Apps — набір для спільної роботи в хмарі.

6. MindMeister — створення «карти розуму» для власної організації діяльності.

\section{Путівники з електронної освіти онлайн:}

1. A 21st Century Reading List — путівник з інновацій.

2. Design Your Own Education - путівник з безперервного навчання.

3. The Best iOS Education Apps - путівник з навчання за допогою iPhone.

4. The Best Android Education Apps — мобільне навчання на Андроїд.

5. The Hyper Learning Toolkit — безкоштовне навчання в безперервному професійному розвитку. 
Інформаційні інструменти, що рекомендуються здобувачеві для самонавчання

\begin{tabular}{|c|c|c|c|}
\hline $\begin{array}{c}\text { Назва } \\
\text { Інтернет- } \\
\text { платформи }\end{array}$ & $\begin{array}{c}\text { Країна } \\
\text { походження, } \\
\text { рік }\end{array}$ & Можливості & Оплата \\
\hline Zoom & $\begin{array}{l}\text { США, } \\
2013\end{array}$ & $\begin{array}{l}\text { Широкі, доступна для невеликих } \\
\text { груп. Професійна система, важ- } \\
\text { ливе рішення для телемедицини }\end{array}$ & Безкоштовні та платні версії \\
\hline Moodle & $\begin{array}{l}\text { Австралія, } \\
2000\end{array}$ & $\begin{array}{c}\text { Професійна з дуже широким за- } \\
\text { стосуванням }\end{array}$ & $\begin{array}{c}\text { Безкоштовна, } \\
\epsilon \text { платні модулі }\end{array}$ \\
\hline Прометеус & $\begin{array}{l}\mathrm{P} \Phi \\
2012\end{array}$ & $\begin{array}{c}\text { Готовий продукт. } \\
\text { Система має модульну архітекту- } \\
\text { ру, що дозволяє її розширювати, } \\
\text { модернізувати, масштабувати при } \\
\text { необхідності }\end{array}$ & $\begin{array}{c}\text { Платні та безкоштовні версії. } \\
\text { Перша в Україні платформа з онлайн } \\
\text { курсами. Містить серії лекцій від ви- } \\
\text { кладачів НТУУ «КПІ імені Ігоря Сі- } \\
\text { корського» та НУ «Києво-Могилянська } \\
\text { академія» }\end{array}$ \\
\hline Coursera & $\begin{array}{l}\text { США, } \\
2012\end{array}$ & $\begin{array}{c}\text { Понад } 2000 \text { курсів. Всі лекції } \\
\text { доступні для скачування. Основа } \\
\text { — академічне навчання з ключо- } \\
\text { вими датами }\end{array}$ & Платна, є безкоштовні гранти \\
\hline
\end{tabular}

Висновки. 1. Медична та біологічна інформатика і кібернетика — системоутворюючий напрям знань. За своєю структурою він є міждисциплінарною та трансдисциплінарною дисципліною.

2. Представлено освітню програму та навчальний план підготовки здобувачів вищої освіти ступеня доктора філософії на третьому (освітньо-науковому) рівні за всіма формами навчання для спеціалізації «Медична та біологічна інформатика і кібернетика».

3. Кінцеві цілі з навчальної дисципліни «Медична та біологічна інформатика і кібернетика» спрямовані на здобуття глибинних знань зі спеціальності, за якою здобувач проводить дослідження.

4. Запропоновано обговорення освітньої програми та навчального плану з метою прийняття їх як уніфікованих. 


\section{Література.}

1. Спільна декларація міністрів освіти Європи. - Болонья, 19 червня 1999 року. - Режим доступу: https:// zakon.rada.gov.ua/laws/show/994_525.

2. Конвенція «Про визнання кваліфікацій вищої освіти в європейському регіоні» (Лісабон, 1997 р.). - Режим доступу: https:/www.coe.int/ru/web/conventions/fulllist/-/conventions/treaty/165.

3. Закон України «Про вищу освіту» із змінами від 01.07.2014 № 1556-VII. - Режим доступу: https:// zakon.rada.gov.ua/laws/show/1556-18.

4. Постанова Кабінету Міністрів України «Про затвердження Порядку підготовки здобувачів вищої освіти ступеня доктора філософії та доктора наук у вищих навчальних закладах (наукових установах)» із змінами від 23. 03.2016 № 261. - Режим доступу: https:// zakon.rada.gov.ua/laws/show/261-2016-\%D0\%BF.

5. Постанова Кабінету Міністрів України «Про затвердження Ліцензійних умов провадження освітньої діяльності закладів освіти» із змінами від 30.12.2015 № 1187. - Режим доступу: https://zakon.rada.gov.ua/ laws/show/1187-2015-\%D0\%BF.

6. Болонський процес та нова парадигма вищої освіти: монографія / Ю. М. Рашкевич ; М-во освіти і науки України, Нац. ун-т «Львів. політехніка». - Львів: Вид-во Львів. політехніки, 2014. - 168 с.

7. Медична інформатика і кібернетика в охороні здоров’я та медицині : Уніфікована програма післядипломного навчання лікарів і провізорів (Частина 1) / О. П. Мінцер, Ю. В. Вороненко, Л. Ю. Бабінцева, C. I. Мохначов // Медична інформатика та інженерія. - 2016. - № 4. - С. 54-93.

8. Медична інформатика і кібернетика в охороні здоров’я та медицині: Уніфікована програма післядипломного навчання лікарів і провізорів (Частина 2) / О. П. Мінцер, Ю. В. Вороненко, Л. Ю. Бабінцева, С. І. Мохначов // Медична інформатика та інженерія. -2017.-№ 1.-С. 43-103.

9. Медична інформатика і кібернетика в охороні здоров’я та медицині: Уніфікована програма післядипломного навчання лікарів і провізорів (Частина 3) / О. П. Мінцер, Ю. В. Вороненко, Л. Ю. Бабінцева, С. І. Мохначов // Медична інформатика та інженерія. -2017.-№ 2.-С. 37-103.

10. Медична інформатика і кібернетика в охороні здоров’я та медицині: Уніфікована програма післядипломного навчання лікарів і провізорів (Частина 4) / О. П. Мінцер, Ю. В. Вороненко, Л. Ю. Бабінцева, C. I. Мохначов // Медична інформатика та інженерія. - 2017. - № 3. - С. 37-103.

11. Медична та біологічна інформатика і кібернетика - здобувачу наукового ступеня / О. П. Мінцер, О. В. Гойко, К. О. Чалий. - К.: Знання України, 2007. - 60 с.

\section{References.}

1. Joint Declaration of the Ministers of Education of Europe. - Bologna, 19 June 1999. - URL: https://zakon.rada.gov. ua/laws/show/994_525.
2. Convention on the Recognition of Qualifications in Higher Education in the European Region (Lisbon, 1997). - URL: https://www.coe.int/ru/web/conventions/ full-list/-/conventions/treaty/165.

3. Zakon Ukrainy «Pro vyshchu osvitu» iz zminamy vid 01.07.2014 № 1556-VII [Law of Ukraine «On Higher Education» with changes from 01.07.2014 № 1556-VII]. URL: https://zakon.rada.gov.ua/laws/show/1556-18. [In Ukrainian].

4. Postanova Kabinetu Ministriv Ukrainy «Pro zatverdzhennia Poriadku pidhotovky zdobuvachiv vyshchoi osvity stupenia doktora filosofii ta doktora nauk u vyshchykh navchalnykh zakladakh (naukovykh ustanovakh)» iz zminamy vid 23.03.2016 № 261 [The Resolution of the Cabinet of Ministers of Ukraine «On Approval of the Procedure for Preparing Graduates of Higher Education for Doctor of Philosophy and Doctor of Sciences in Higher Educational Institutions (Scientific Institutions)» as amended March 23, 2016 No. 261]. URL: https://zakon.rada.gov.ua/laws/show/261-2016\%D0\%BF. [In Ukrainian]

5. Postanova Kabinetu Ministriv Ukrainy «Pro zatverdzhennia Litsenziinykh umov provadzhennia osvitnoi diialnosti zakladiv osvity» iz zminamy vid 30.12.2015 № 1187 [Resolution of the Cabinet of Ministers of Ukraine «On Approval of Licensing Conditions for Conducting Educational Activities of Educational Institutions», as amended on December 30, 2015 No. 1187]. - URL: https://zakon.rada.gov.ua/laws/ show/1187-2015-\%D0\%BF. [In Ukrainian]

6. Rashkevych, Yu. M. (2014). Bolonskyi protses ta nova paradyhma vyshchoi osvity: monohrafiia [The Bologna Process and the New Paradigm of Higher Education: Monograph]. M-vo osvity i nauky Ukrainy, Nats. un-t «Lviv. politekhnika» (Ministry of Education and Science of Ukraine, National Academy of Sciences of Ukraine. University Lviv Polytechnic University). - Lviv: Vyd-vo Lviv. Politekhniky . [In Ukrainian].

7. Mintser, O. P., Voronenko, Yu. V., Babintseva, L. Yu., Mokhnachov, S. I. (2016). Medychna informatyka i kibernetyka v okhoroni zdorovia ta medytsyni : Unifikovana prohrama pisliadyplomnoho navchannia likariv i provizoriv (Chastyna 1) [Medical informatics and cybernetics in health and medicine: Unified program of postgraduate education of doctors and pharmacists (Part 1)]. Medychna informatyka ta inzheneriia (Medical informatics and engineering), 4, 54-93. [In Ukrainian].

8. Mintser, O. P., Voronenko, Yu. V., Babintseva, L. Yu., Mokhnachov, S. I. (2017). Medychna informatyka i kibernetyka v okhoroni zdorovia ta medytsyni : Unifikovana prohrama pisliadyplomnoho navchannia likariv i provizoriv (Chastyna 2) [Medical informatics and cybernetics in health and medicine: Unified program of postgraduate education of doctors and pharmacists (Part 2)]. Medychna informatyka ta inzheneriia (Medical informatics and engineering), 1, 43-103. [In Ukrainian]. 
9. Mintser, O. P., Voronenko, Yu. V., Babintseva, L. Yu., Mokhnachov, S. I. (2017). Medychna informatyka i kibernetyka v okhoroni zdorovia ta medytsyni : Unifikovana prohrama pisliadyplomnoho navchannia likariv i provizoriv (Chastyna 3) [Medical informatics and cybernetics in health and medicine: Unified program of postgraduate education of doctors and pharmacists (Part 3)]. Medychna informatyka ta inzheneriia (Medical informatics and engineering), 2, 37-103. [In Ukrainian].

10. Mintser, O. P., Voronenko, Yu. V., Babintseva, L. Yu., Mokhnachov, S. I. (2017). Medychna informatyka i kibernetyka v okhoroni zdorovia ta medytsyni :
Unifikovana prohrama pisliadyplomnoho navchannia likariv i provizoriv (Chastyna 4) [Medical informatics and cybernetics in health and medicine: Unified program of postgraduate education of doctors and pharmacists (Part 4)]. Medychna informatyka ta inzheneriia (Medical informatics and engineering), 3, 37-103. [In Ukrainian]. 11. Mintser, O. P., Gojko, O. V., Chalyy, K. O. (2007). Medychna ta biologichna informatyka i kibernetyka - zdobuvachu naukovoho stupenya [Medical and biological informatics and cybernetics for a scientific degree]. K.: Znannya Ukrayiny (Knowledge of Ukraine), 60. [In Ukrainian]. 